\title{
Physiology and pathophysiology of matrix metalloproteases
}

\author{
T. Klein $\cdot$ R. Bischoff
}

Received: 14 February 2010/ Accepted: 2 July 2010/Published online: 18 July 2010

(C) The Author(s) 2010. This article is published with open access at Springerlink.com

\begin{abstract}
Matrix metalloproteases (MMPs) comprise a family of enzymes that cleave protein substrates based on a conserved mechanism involving activation of an active site-bound water molecule by a $\mathrm{Zn}^{2+}$ ion. Although the catalytic domain of MMPs is structurally highly similar, there are many differences with respect to substrate specificity, cellular and tissue localization, membrane binding and regulation that make this a very versatile family of enzymes with a multitude of physiological functions, many of which are still not fully understood. Essentially, all members of the MMP family have been linked to disease development, notably to cancer metastasis, chronic inflammation and the ensuing tissue damage as well as to neurological disorders. This has stimulated a flurry of studies into MMP inhibitors as therapeutic agents, as well as into measuring MMP levels as diagnostic or prognostic markers. As with most protein families, deciphering the function(s) of MMPs is difficult, as they can modify many proteins. Which of these reactions are physiologically or pathophysiologically relevant is often not clear, although studies on knockout animals, human genetic and epigenetic, as well as biochemical studies using natural or synthetic inhibitors have provided insight to a great extent. In this review, we will give an overview of 23 members of the human MMP family and describe functions, linkages to disease and structural and mechanistic features. MMPs can be grouped into soluble (including matrilysins) and
\end{abstract}

T. Klein $\cdot$ R. Bischoff $(\square)$

Department of Pharmacy, Analytical Biochemistry,

University of Groningen, Antonius Deusinglaan 1,

9713 AV Groningen, The Netherlands

e-mail: r.p.h.bischoff@rug.nl membrane-anchored species. We adhere to the 'MMP nomenclature' and provide the reader with reference to the many, often diverse, names for this enzyme family in the introduction.

Keywords Matrix metalloprotease - Cancer . Chronic obstructive pulmonary disease $\cdot$ MMP . Function · Inhibitor · Review

\section{Introduction}

Metzincins are a ubiquitously expressed family of multidomain zinc (II)-dependent endopeptidases (Stocker and Bode 1995), the members of which include well-known metalloproteases such as the matrix metalloproteases (MMPs) (Nagase and Woessner 1999), a disintegrin and metalloproteases (ADAMs) (White 2003), the ADAMs with a thrombospondin motif (ADAMTS) (Tang 2001), the bacterial serralysins (Nakahama et al. 1986) and proteases such as the astacins (including the meprins) (Bode et al. 1992; Butler et al. 1987). This superfamily of proteases is defined by the presence of a $\mathrm{Zn}^{2+}$ ion at the catalytic center, which is coordinated by three histidine residues in the zinc-binding consensus sequence HExxHxxGxxH that is present in all proteolytically active metzincins, and a characteristic, strictly conserved methionine-containing tight 1,4 beta turn forming a hydrophobic cleft for the catalytic zinc ion (Bode et al. 1993). Catalysis of protein substrates is (most probably) carried out via a general base mechanism involving activation of a zinc-bound water molecule by the carboxylate group of the conserved glutamate residue in the catalytic pocket followed by attack of water on the polarized carbonyl group in the substrate's scissile bond (Browner et al. 1995). 
The main physiological function of these proteases was originally ascribed to the modulation and regulation of extracellular matrix (ECM) turnover by direct proteolytic degradation of the ECM proteins (e.g., collagen, proteoglycans and fibronectin) (Woessner 1991). Another important function is the liberation of biologically active proteins such as cytokines, growth factors and chemokines from their membrane-anchored proforms (so-called shedding). More comprehensive "degradomics" approaches indicate, however, that this view is likely too limited (Butler and Overall 2009). MMPs thus contribute to the generation of protein species with vastly differing activities from a single, original gene product.

\section{Matrix metalloproteases}

Matrix metalloproteases or matrixins (see Table 1) are a subfamily of metalloproteases, which consist of 23 distinct proteases in humans (24 in mouse). The first MMP was identified in 1962 as the protease responsible for the degradation of fibrillar collagen in tadpole tails during metamorphosis and was thus dubbed interstitial collagenase (Gross and Lapiere 1962). After identification of a similar collagenase in human skin, this protease was renamed MMP-1. MMPs have since been identified as the major enzymes responsible for turnover of extracellular matrix by proteolytic degradation of virtually all proteinaceous components of the ECM (Woessner 1991).

MMPs are largely excreted proteins with several conserved domains (see Fig. 1). All MMPs contain the catalytic domain, which is shielded off in the inactive form of the enzyme by the prodomain. This propeptide interacts with the catalytic region through a conserved cysteine residue and the $\mathrm{Zn}^{2+}$ ion in the catalytic pocket (the socalled cysteine switch) (Nagase 1997; Van Wart and Birkedal-Hansen 1990). Except for MMP-7, MMP-23 and MMP-26, all MMPs contain a C-terminal hemopexin-like domain that functions primarily as a recognition sequence for the substrate (Murphy and Knauper 1997). Although MMPs retain catalytic activity toward a wide range of substrates when missing this domain, the hemopexin domain, which is structured like a four-bladed propeller structure with each blade consisting of four antiparallel $\beta$-sheets and one $\alpha$-helix, is an absolute necessity for the degradation of triple-helical collagens (Bode 1995). The gelatinases (MMP-2 and -9) further contain a series of three fibronectin type II inserts in the catalytic domain, which facilitate binding of gelatine and collagen (Bode et al. 1999).

MMP function is regulated at several levels. Firstly, induction of gene expression is controlled by number growth factors and cytokines, and may be suppressed by transforming growth factor $\beta$ and glucocorticoids (Nagase
Table 1 Overview of the 23 identified human matrix metalloproteases and their common names

\begin{tabular}{llll}
\hline MMP & Alternative name & MMP & Alternative name \\
\hline 1 & Collagenase-1 & 16 & Membrane type-3 MMP \\
& Interstitial collagenase & & \\
2 & Gelatinase A & 17 & Membrane type-4 MMP \\
& 72-kDa type IV collagenase & & \\
3 & Stromelysin-1 & 19 & None \\
& Transin-1 & & Human ortholog of Xenopus MMP-18 \\
7 & Matrilysin & 20 & Enamelysin \\
& Pump-1 & & \\
8 & Collagenase-2 & 21 & None \\
& Neutrophil collagenase & & Human ortholog of Xenopus xMMP \\
9 & Gelatinase B & 23 & Cysteine array MMP \\
& $92-k D a$ type IV collagenase & & Femalysin \\
& & & MMP-22 \\
10 & Stromelysin-2 & 24 & Membrane type-5 MMP \\
11 & Stromelysin-3 & 25 & Membrane type-6 MMP \\
& & & Leukolysin \\
12 & Macrophage metallo-elastase & 26 & Matrilysin-2/endometase \\
13 & Collagenase-3 & 27 & None \\
14 & Membrane type-1 MMP & 28 & Epilysin \\
15 & Membrane type-2 MMP & & \\
\hline & & &
\end{tabular}




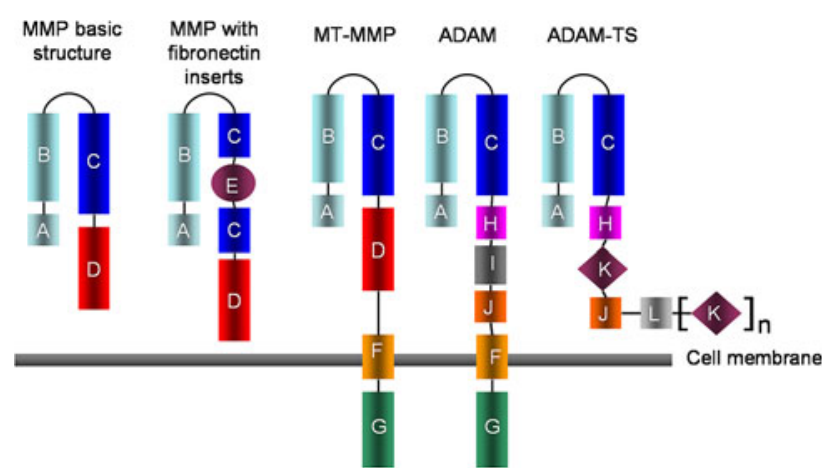

Fig. 1 Schematic representation of the domain structure of metzincin proteases. A signal peptide, $B$ prodomain, $C$ catalytic domain, $D$ hemopexin-like domain, $E$ fibronectin type II insert, $F$ transmembrane domain, $G$ cytoplasmic tail, $H$ disintegrin domain, $I$ cysteinerich domain, $J$ EGF-like domain, $K$ thrombospondin type I-like repeat, $L$ spacer region

and Woessner 1999; Vincenti 2001). Recent insights indicate an important modulatory role of epigenetic processes in the expression of MMPs (Chernov et al. 2009). Besides soluble factors, MMP expression may also be regulated by cell-cell contact or interaction of cells with ECM components such as EMMPRIN (extracellular matrix metalloprotease inducer or CD147) (Biswas et al. 1995). The expressed MMPs are largely excreted as inactive proenzymes with the propeptide effectively limiting entrance into and catalysis of a substrate in the catalytic pocket by blocking the catalytic zinc (II) ion via the cysteine switch mechanism. Activation of proMMPs can occur through several mechanisms [reviewed in Ra and Parks (2007)], all of which lead to disruption of the cysteine switch. Perhaps, the most important mechanism is proteolytic removal of the prodomain by other endopeptidases such as furin (Pei and Weiss 1995). Removal of the prodomain of MMPs, which contains a furin-like proprotein convertase recognition site (RRKR or RxKR), has been described for nine MMPs including all membrane-type MMPs. Alternatively, the prodomain can be proteolytically removed by plasmin and other serine proteases, or even other MMPs. This mechanism is well described for MMP-2 where proMMP-2 binds the endogenous MMP inhibitor TIMP-2 (tissue inhibitor of metalloproteases 2). This complex in turn functions as a ligand for the membrane-bound MMP-14 (or membrane-type 1 MMP) leading to activation of MMP-2 (Cao et al. 1996).

The cysteine switch may also be broken by chemical reactions, either physiologically by oxidation of cysteine by reactive oxygen species, or artificially by mercurycontaining compounds such as 4-aminophenylmercuric acetate (APMA) or denaturing surfactants such as sodium dodecyl sulfate (SDS). This disruption of the thiol-zinc interaction leads to allosteric relocation of the prodomain leading to active forms of the enzyme with the propeptide still attached or to autoproteolytic removal of the relocated prodomain. MMPs are inhibited by the general protease inhibitor $\alpha_{2}$-macroglobulin and a small family of natural inhibitors specifically geared toward inhibiting metalloprotease activity. These TIMPs are a group of four proteins (21-30 $\mathrm{kDa}$ in size) that as a group effectively inhibit all MMPs in vivo (Gomez et al. 1997).

Excreted MMPs are generally classified according to their substrate specificity, leading to four classes: the collagenases (MMP-1, -8 and -13), the gelatinases (MMP-2 and -9), the stromelysins (MMP-3, -10 and -11) and a heterogeneous group containing matrilysin (MMP-7), metallo-elastase (MMP-12), enamelysin (MMP-20), endometase (MMP-26) and epilysin (MMP-28). In this nomenclature, the membrane-anchored MMPs (MMP-14, $-15,-16,-17,-24$ and -25$)$ are considered as a separate class. An alternate classification arranges the MMPs according to their domain structure (Sternlicht and Werb 2001).

\section{Soluble MMPs: collagenases}

\section{MMP-1}

MMP-1 or collagenase-1 was the first described matrix metalloprotease and has sparked a large volume of research on the physiological and pathological role of MMPs. MMP-1 is a secreted enzyme and contains the hemopexinlike domain necessary for degradation of triple-helical collagens. ProMMP-1 is probably activated via a two-step proteolytic process involving either mast cell tryptase (Gruber et al. 1989) or urokinase (Iba et al. 2000) and MMP-3. Mature collagenase- 1 can be found as two distinct forms: a major 57-kDa species and a minor, glycosylated 61-kDa form (Pardo and Selman 2005). The active enzyme is inhibited by TIMP-1.

MMP-1 has a wide substrate specificity and is capable of degrading aggrecan, versican, perlecan, nidogen, serpins and tenascin-C (McCawley and Matrisian 2001). Since MMP-1 does contain the hemopexin domain, it is one of the MMPs capable of proteolytic cleavage of fibrillar collagen leading to unwinding of the triple-helical structure that leaves collagen (or gelatine) highly susceptible to degradation by other proteases. Proteolysis by MMP-1 has also been implicated in the release of membrane-anchored proforms of insulin growth factor-binding proteins (IGFBP-3 and -5 ), IL-1 $\beta$ and L-selectin, among others (McCawley and Matrisian 2001).

Since mice lack a clear ortholog of human MMP-1, definition of the physiological role by creating knockout mice has not been possible, but transgenic mice that express human MMP-1 are known to develop lung 
emphysema, indicating a possible role for MMP-1 in development of this disease (D'Armiento et al. 1992). Other experiments with transgenic mouse strains have revealed development of skin disorders such as hyperkeratosis and bone growth retardation (D'Armiento et al. 1995; Imai et al. 2007). Since MMP-1 appears to play a key role in the turnover of ECM, deregulation of MMP-1 activity has been hypothesized to be involved in various diseases related to excessive or insufficient ECM turnover, such as arthritis (Vincenti et al. 1994; Vincenti and Brinckerhoff 2002), cancer (Benbow et al. 1999; Brinckerhoff et al. 2000), wound healing disorders (Muller et al. 2008) and fibrotic diseases (Iredale et al. 1998). MMP-1 expression has been reported to be sensitive to oxidative stress (Alge-Priglinger et al. 2009) and cigarette smoke exposure in an ERK 1/2-dependent mechanism (Mercer et al. 2009). MMP-1 activity may be regulated by redox mechanisms with low molecular weight thiols, such as glutathione and (homo)cysteine, inactivating MMP-1 by interaction with the catalytic $\mathrm{Zn}^{2+}$ ion and thus mimicking the cysteine switch, an effect that can be abrogated by oxidizing radicals (Koch et al. 2009).

Although many studies have found a positive correlation between MMP-1 expression and disease, it has proven difficult to clearly identify MMP-1 as a systemic marker of the investigated disease. A recent study identified the level of circulating MMP-1 as a possible prognostic marker for the plaque burden in atherosclerosis, but the authors were unable to differentiate calcified and non-calcified plaques based solely on MMP-1 levels in serum (Lehrke et al. 2009). Experiments with local sampling have proven more accurate, for instance in the analysis of MMP-1 in synovial fluid of rheumatoid arthritis patients, where MMP-1 levels correlated with inflammatory activity (Maeda et al. 1995; Peake et al. 2005).

\section{MMP-8}

MMP-8 (neutrophil collagenase or collagenase-2) is very similar to MMP-1 in structure and physiological function, although subtle differences in substrate selectivity exist. MMP-8 has a stronger affinity toward type I collagen than MMP-1, while MMP-1 preferentially cleaves type III collagen (Balbin et al. 1998). Neutrophil collagenase was first described in 1990 when it was cloned from neutrophils obtained from a patient with granulocytic leukemia (Hasty et al. 1990). Contrary to MMP-1, MMP-8 is not released immediately after synthesis, but rather stored in specific granules that release the active enzyme on stimulation (Schettler et al. 1991). As with MMP-1, MMP-8 can be activated by proteolytic removal of the propeptide by stromelysin-1 (MMP-3), but also by matrilysin (MMP-7) (Dozier et al. 2006). The mature enzyme is $64 \mathrm{kDa}$ in size, with glycosylation increasing the size to $75 \mathrm{kDa}$. Autoproteolytic degradation has been described, yielding a 40-kDa fragment, which retains catalytic activity but does not cleave fibrillar collagen. MMP-8 activity can be inhibited by TIMP-1 and TIMP-2 (Knauper et al. 1993).

MMP-8 seems to have an important function during embryogenesis and postpartum remodeling of uterine tissue, as demonstrated by expression studies in mice (Balbin et al. 1998). MMP-8 has also been implicated as one of the major contributors to connective tissue turnover in inflammation due to oxidative auto-activation of the enzyme (Weiss et al. 1985). Experimental evidence has shown that purified MMP-8 is capable of degrading $\alpha_{1}$-proteinase inhibitor, which might link increased MMP-8 activity to the pathology associated with pulmonary emphysema (Desrochers et al. 1992). Experiments with MMP-8 null mice demonstrate decreased migration of polymorphonuclear leukocytes into the airway lumen in a heterotopic airway transplant model, indicating a pivotal role of the protease in the development of obliterative bronchiolitis (Khatwa et al. 2010).

The role of MMP-8 in cancer is interesting, since recent findings suggested this MMP to have a protective effect by suppressing tumor metastasis (Gutierrez-Fernandez et al. 2008; Korpi et al. 2008) and by increasing the susceptibility to oncolytic viruses (Mok et al. 2007). On the other hand studies have identified MMP-8 as a promoter of ovarian tumor proliferation (Stadlmann et al. 2003) and high MMP-8 expression seems to be an indicator for poor prognosis (Stenman et al. 2003). This contradicting evidence of the role of MMP-8 in cancer is an indication of the complex, and so far still poorly understood biological roles of MMPs. MMP-8 is further involved in various inflammatory processes, such as atherosclerosis, where both expression as well as protease activity are higher in vulnerable plaques than in stable plaques (Herman et al. 2001; Molloy et al. 2004), indicating that MMP-8 may be useful as a marker for plaque instability in atherosclerosis.

\section{MMP-13}

MMP-13 (collagenase-3) is the latest human collagenase described in literature. This enzyme exhibits preference toward cleavage of type II collagen, effectively completing the substrate spectrum of the collagenases. Collagenase- 3 was first cloned from breast cancer tissue in 1994 (Freije et al. 1994). MMP-13 expression can be influenced by a wide range of hormones and cytokines, such as parathyroid hormone (indicative of the important role of MMP-13 in bone development), insulin-like growth factors I and II, platelet derived growth factor, basic fibroblast growth factor, transforming growth factor $\beta 1$ (interestingly both up- and downregulates MMP-13 expression depending on 
the tissue), interleukin-1 and -6 , tumor necrosis factor $\alpha$ and many more (Leeman et al. 2002). ProMMP-13 can be activated by auto-proteolysis or propeptide removal by various other MMPs like stromelysin-1 (MMP-3), yielding a mature enzyme of $48 \mathrm{kDa}$, which in turn can be inhibited by TIMP-1, -2 and -3 (Knauper et al. 1996). Active MMP13 is a key factor in the activation pathway of several MMPs. Besides the TIMP route of inactivation, MMP-13 can bind to a specific receptor on the surface of osteoblasts and fibroblasts resulting in internalization and degradation of the protease (Barmina et al. 1999).

MMP-13 plays an important role in bone development and remodeling, as may be anticipated from its capability to cleave type II collagen (a major component of cartilage). This rather specific function is reflected in a limited expression profile of MMP-13 during development and adulthood, which is restricted to developing skeletal tissue. MMP-13 has, contrary to the other collagenases, a relatively high specific activity toward gelatine, indicating that the proteolytic role of MMP-13 expands past the first step of cleavage of triple-helical collagens. Further identified substrates of MMP-13 include aggrecan and perlecan, transforming growth factor $\beta$, biglycan, the large protein species of tenascin-C, fibrillin- 1 and -2 , fibrinogen and two serpins $\left(\alpha_{2}\right.$-antichymotrypsin and plasminogen activator inhibitor-2) (Leeman et al. 2002).

MMP-13 expression has been regularly referred to in the literature as indicative of various cancerous processes including chondrosarcoma, breast cancer, head and neck tumors and melanoma (Balbin et al. 1999). In all cases, high expression of MMP-13 seems to be related to aggressiveness of the tumor, and MMP-13 may even be required for metastasis of certain tumors as demonstrated for malignant melanoma (Zigrino et al. 2009).

Regarding the important role of MMP-13 in bone turnover, it is not surprising that this enzyme has been linked to various bone-related diseases. Since MMP-13 degrades both type II collagen and aggrecan, it has been linked to cartilage destruction in rheumatoid and osteoarthritis (Burrage et al. 2006). The specialized role of MMP-13 in bone development and disease has made it an attractive target for selective MMP-13 inhibitors as therapeutic compounds (Heim-Riether et al. 2009; Hu et al. 2005; Jungel et al. 2010; Leeuwenburgh et al. 2006).

\section{Soluble MMPs: gelatinases}

\section{MMP-2}

MMP-2 (gelatinase A, 72-kDa type IV collagenase) is one of the two described human gelatinases in the MMP family, named for their ability to proteolytically degrade gelatine (denatured collagen). MMP-2 is ubiquitously expressed as a $72-\mathrm{kDa}$ proenzyme and subject to extensive glycosylation. Expression of MMP-2 is constitutive and most proinflammatory stimuli fail to increase the expression level since the gene, in contrast to that of MMP-9, lacks binding sites for pro-inflammatory transcription factors such as activator protein-1 (Templeton and Stetler-Stevenson 1991).

The MMP-2 proenzyme is activated by forming a complex with TIMP-2 under appropriate stoichiometric conditions, which in turn is a substrate for the membranebound membrane type-1 MMP (MMP-14) that removes the prodomain of proMMP-2 by proteolytic cleavage (aided by free active MMP-2), yielding the truncated 64-kDa active enzyme (Deryugina et al. 2001). If the concentration of TIMP-2 is too high, both MMP-14 and active MMP-2 will be inhibited, and no further activation will ensue. Besides this activation pathway, proMMP-2 can also be activated by thrombin and activated protein C (Nguyen et al. 2000).

MMP-2 differs from other MMPs in that the catalytic domain contains cysteine-rich inserts that resemble the collagen-binding regions of the type II repeats in fibronectin. These inserts are required for binding and cleavage of collagen and elastin (Murphy et al. 1994). MMP-2 is capable of cleaving gelatine, type I, IV and V collagens, elastin and vitronectin (Chakrabarti and Patel 2005). Through their ability to degrade collagen in the vascular basal membranes, the gelatinases are involved in neovascularization (Nguyen et al. 2001) both under physiological conditions and in pathologies such as tumor metastasis. The state of activation seems to be of crucial importance for the function of MMP-2 in angiogenesis. Recent research has demonstrated that the fully mature active form induces apoptosis in endothelial cells and inhibits neovascularization, while an intermediate activated form in complex with MMP-14 enhances cell survival and promotes angiogenesis (Shapiro et al. 2010).

MMP-2 can also facilitate migration of cells by direct degradation of the basement membrane thus allowing infiltration of, for instance, neutrophils and lymphocytes, or liberation of chemoattractants (Nagase 1998). This latter process, named 'ectodomain shedding', is an important physiological function of the membrane-bound ADAM proteases, but has also been described for many other members of the metzincin superfamily. MMP-2 has been known to be involved in both promoting and inhibiting inflammation by liberation of pro-inflammatory mediators [for instance the active form of interleukin-1 $\beta$ (Schonbeck et al. 1998)], proteolytic degradation of chemoattractants [for instance, transforming monocyte chemoattractant protein-3 into the truncated form with antagonistic properties on the $\mathrm{CC}$ chemokine receptor (McQuibban et al. 2002)] and a profound role in the chemotactic gradient that 
is necessary in the clearance of inflammatory cells from tissue (Corry et al. 2002). Recent evidence from proteomics studies shows that the role of MMP-2 in processing signaling proteins may be much greater than originally anticipated, which, if confirmed for other MMPs, could lead to a paradigm shift in the physiological role of these proteases (Dean et al. 2007; Dean and Overall 2007).

Interestingly, MMP-2 knockout mice exhibit a normal phenotype under physiological conditions, although the animals do show different response patterns upon allergen challenge, which may be attributed to disturbance of the important role of clearing immune cells (Corry et al. 2002). These findings indicate that MMP-2 function may be interchangeable with other metalloproteases, a hypothesis that is supported by the observation that expression of the second gelatinase, MMP-9, is greatly increased in MMP-2 null mice (Esparza et al. 2004).

\section{MMP-9}

MMP-9 (gelatinase B, 92-kDa type IV collagenase) was first discovered in neutrophils in 1974 (Sopata and Dancewicz 1974). MMP-9 is expressed as a $92-\mathrm{kDa}$ proenzyme, which can be activated to the $83-\mathrm{kDa}$ mature enzyme. The larger size of MMP-9 relative to MMP-2 can be attributed to a heavily O-glycosylated collagen V-like insert that links the metalloprotease domain to the hemopexin-like domain (Mattu et al. 2000). MMP-9 activation may be mediated by removal of the prodomain by serine proteases or other MMPs (Ogata et al. 1992), or may be a direct response to oxidative stress that disrupts the cysteine switch (Maeda et al. 1998). While a considerable overlap exists in the substrates degraded by MMP-2 and -9, MMP-9 is incapable of direct proteolysis of collagen I (Chakrabarti and Patel 2005).

MMP-9 has been described to release the biologically active form of vascular endothelial growth factor (VEGF), which plays an important role in angiogenesis. This process is complemented by the direct proteolytic degradation of vascular basement membrane proteins, indicating that MMP-9 (even more than MMP-2) may play a crucial role in the formation of new blood vessels (Bergers et al. 2000). Interestingly, the hemopexin domain of MMP-9 was reported to be an inhibiting factor in angiogenesis as demonstrated by decreased invasion of glioblastoma cells overexpressing the MMP-9 hemopexin domain in a xenograft model (Ezhilarasan et al. 2009).

MMP-9 plays an important role in migration of immune cells as demonstrated by the reduced presence of neutrophils, lymphocytes and dendritic cells in brochoalveolar lavage fluid (BALF) of MMP-9 knockout mice after antigen challenge (Lemjabbar et al. 1999). MMP-9 null mice show decreased fertility, since MMP-9 is crucial during several stages of the female reproductive cycle (implantation of the embryo and remodeling of endometrial tissue that occurs during the menstrual cycle) (Dubois et al. 2000). Absence of MMP-9 also leads to disorders in bone development, specifically delayed bone ossification due to insufficient angiogenesis in growth plates (Vu et al. 1998) and reduced osteoclast recruitment (Engsig et al. 2000). The biological roles of MMP-9 have been extensively reviewed in (Van den Steen et al. 2002).

MMP-9 is capable of processing cytokines and chemokines similarly to MMP-2. MMP-9 cleaves interleukin- 8 to its more potent truncated form, activates IL- $1 \beta$ and transforming growth factor $\beta$ (Chakrabarti and Patel 2005). Proteomics techniques revealed a role of active MMP-9 in shedding $\beta 2$ integrin from macrophages (Vaisar et al. 2009). Whereas MMP-2 is primarily inhibited by TIMP-2, MMP-9 is mostly inhibited by TIMP-1 (Crocker et al. 2004). Contrary to MMP-2, which is expressed ubiquitously under physiological conditions, MMP-9 is only present constitutively in neutrophils (Devarajan et al. 1992), where it is stored in granules to be rapidly released after stimulation. Expression in many other cell types is inducible by (inflammatory) stimuli (Opdenakker et al. 1991), is increased in malignant cell lines and correlates with their metastatic potential (Baruch et al. 2001). Neutrophil-derived MMP-9 is distinguishable from other sources since it forms a covalent complex with neutrophil gelatinase B-associated lipocalin (NGAL) (Kjeldsen et al. 1993).

The role of gelatinases in pathology has been studied extensively, especially in lung diseases [reviewed in Chakrabarti and Patel (2005)] and cancer [reviewed in e.g. Bjorklund and Koivunen (2005) and Klein et al. (2004)]. The amount of both gelatinases in BALF and sputum of patients suffering from chronic asthma is higher than in healthy individuals and this increase is hypothesized to be mainly due to gelatinases originating from eosinophils, neutrophils and epithelial cells (Maisi et al. 2002; Mautino et al. 1997). This increase may be responsible for the characteristic tissue remodeling events observed in chronic asthma such as thickening of the basement membrane, smooth muscle tissue hypertrophy and reduced epithelial thickness. MMP-2 does not seem to play an important role in the pathophysiology of acute asthma, but MMP-9 and the MMP-9/TIMP-1 ratio are increased in exacerbations of acute asthma (Lemjabbar et al. 1999). This phenomenon may be explained by the presence of a pool of MMP-9 inside infiltrating neutrophils that is released during the asthmatic attack. Since neutrophils do not produce TIMP1 , degranulation leads to a strong increase in the local concentration of proteolytically active MMP-9, which may cause several of the symptoms observed in acute asthma, such as airway obstruction due to desquamation of 
epithelial cells and increased mucus production by goblet cells (Chakrabarti and Patel 2005).

The role of gelatinases in the pathophysiology of chronic obstructive pulmonary disease (COPD) has not been clearly established, but excess protease activity plays an important role in the development and progression of the disease. Sputum and BALF of patients contain elevated concentrations of both MMP-2 and -9. MMP-9 may be an important factor in COPD development, since MMP-9 activity not only causes ECM destruction but has also been described to degrade $\alpha_{1}$-protease inhibitor leading to increased activity of neutrophil elastase and cathepsin $G$ (Chakrabarti and Patel 2005; Liu et al. 2000). MMP-9 is further capable of promoting infiltration of neutrophils (loaded with MMP-9-containing granules) by production of the biologically more active truncated form of IL-8, causing a vicious circle of MMP-9 activity in the diseased lung. Presence and activity of gelatinases is elevated in many other pulmonary diseases, such as cystic fibrosis, bronchiectasis, acute respiratory distress syndrome (ARDS) and infections [reviewed in Chakrabarti and Patel (2005) and Van den Steen et al. (2002)].

\section{Gelatinases in cancer pathology}

The obvious relation of gelatinases to tumor metastasis and angiogenesis has led to a plethora of research papers on the role of MMP-2 and -9 in diverse malignant processes. This hypothesis was first affirmed by the observation that MMP2 knockout mice show decreased tumor angiogenesis and progression (Itoh et al. 1998). Since then, MMPs have been identified as important players in angiogenesis, growth and metastasis of tumors.

The development of a new vascular system is necessary for tumor growth, since without new blood vessels the size of a tumor will be restricted. Gelatinases are primarily involved in this process by enabling proteolytic degradation of the vascular basal membrane, opening the way for migration of endothelial cells to form new blood vessels (Risau 1997). MMP-2 is further capable of cleaving laminin-5, which after degradation yields a cryptic site that increases endothelial cell migration (Risau 1997) and the release of VEGF that stimulates angiogenesis, not only under physiological conditions but also during tumor development. Tumor growth can be stimulated by gelatinase activity, since MMP-2 and -9 have been shown to release growth factors (Levi et al. 1996). Tumor metastasis is a process that involves the release of single tumor cells, migration of these cells to a blood vessel, penetration into the blood stream or lymph system and finally adhesion to vessel endothelium and extravasation into the tissue at the metastatic location. The ECM degrading properties of gelatinases are crucial in both exit of the metastatic cells from the bulk tumor as well as their entrance at the site of metastasis.

Increased gelatinase expression and activity has been described in hundreds of publications related to malignant diseases ranging from breast cancer (Somiari et al. 2006), urogenital cancers (Maatta et al. 2007; Sier et al. 2000; Takemura et al. 1992), brain tumors (Forsyth et al. 1999), lung cancer (Nawrocki et al. 1997), skin cancer (Pyke et al. 1992), colorectal cancer (Murnane et al. 2009) and many more. Interestingly, many authors have found a positive correlation between gelatinase expression or activity and the invasive potential of the tumor, again stressing the crucial role that MMP-2 and -9 play in metastasis. A comprehensive review of the literature on the role of gelatinases in individual cancers is beyond the scope of this article, but excellent reviews are available (Van den Steen et al. 2002).

Besides in pulmonology and oncology, gelatinase activity is under investigation in several other research fields. MMP-2 has, for example, been identified as a possible target in cardiovascular disease, since it was identified as the protease responsible for degradation of the vasodilator peptide andrenomedullin, with one of the resulting fragment peptides having vasoconstrictive properties, possibly leading to hypertension (Martinez et al. 2004).

\section{Soluble MMPs: stromelysins}

\section{MMP-3}

MMP-3 or stromelysin-1 was first described in 1985 as a 51-kDa protein secreted by rabbit fibroblasts (Chin et al. 1985). MMP-3 could be distinguished from collagenases by the inability to degrade type I collagen. More or less simultaneously, a protease named transin was described in transformed rat cells, which later was identified to correspond to MMP-3 (Matrisian et al. 1985, 1986). Stromelysins have a basic MMP structure, with a hemopexin-like domain. The $51-\mathrm{kDa}$ latent proenzyme can be activated by proteolytic removal of the prodomain by, for instance, the serine proteases trypsin-2 (Moilanen et al. 2003) and matriptase (Jin et al. 2006), yielding a 43-kDa active enzyme in humans. MMP-3 is upregulated on exposure to interleukin $1 \beta$ and downregulated by retinoic acid and dexamethasone (Saus et al. 1988).

The substrate specificity of MMP-3 is broad and MMP-3 has been described to degrade many ECM proteins such as fibronectin, denatured collagens (gelatin), laminin and proteoglycans. MMP-3 is incapable of degrading triplehelical collagens, but can cleave the globular portion of type IV collagen (McDonnell and Matrisian 1990). Besides 
degradation of ECM, component MMP-3 is also involved in the activation cascade of the gelatinases and MMP-13. The physiological function of MMP-3 is, surprisingly, not well described in literature, but is assumed to be mainly related to the turnover of extracellular matrix. MMP-3 is highly upregulated in mammary tissue during involution after the lactation period and seems to have a pro-apoptotic effect (Witty et al. 1995).

In vitro experiments with cultured cells have identified a few membrane-bound signaling proteins that may be released by MMP-3 [e.g., E-cadherin (Lochter et al. 1997) and Fas ligand (Matsuno et al. 2001)], but the physiological relevance of these findings is unclear. One well-described substrate of MMP-3 is plasminogen activator inhibitor-1 (PAI-1) (Lijnen et al. 2000). ProMMP-3 can also form a complex with tissue-type plasminogen activator, which increases the activity of t-PA (Arza et al. 2000). These findings may be indicative of an important regulatory function of MMP-3 in the fibrinolytic pathway.

MMP-3 has been described as an important factor in the development of arthritis (Green et al. 2003), asthma (Dahlen et al. 1999), aneurism (Silence et al. 2001), impaired wound healing (Fray et al. 2003), Alzheimer's disease (Yoshiyama et al. 2000) and various cancers (Mercapide et al. 2003; Wiesen and Werb 1996). Recent insights and studies demonstrate that association of MMP-3 with disease states (especially cancer) is uncertain, as many newer studies do not find a positive correlation between MMP-3 and disease. This observation may be (partially) explained by the function of MMP-3 as an activator of other MMPs, which makes identification of the protease 'culprit' difficult.

\section{MMP-10}

The cloning of rat transin/MMP-3 in 1985 quickly led to the identification of a second stromelysin. This protease, named transin-2 (Breathnach et al. 1987), and later identified in humans as stromelysin-2 (Muller et al. 1988) or MMP-10, has $82 \%$ sequence homology with MMP-3 (Sirum and Brinckerhoff 1989). MMP-10 is secreted as a $53-\mathrm{kDa}$ proenzyme and is activated to a $47-\mathrm{kDa}$ mature protease. Originally, MMP-10 production was thought to be relatively unaffected by stimuli such as cytokines and hormones (Brinckerhoff et al. 1992), but recent studies have shown results that indicate the contrary (Barksby et al. 2006).

The physiological function of MMP-10 is poorly understood, with only a handful of publications dealing with characterization of this protease. The in vitro substrate specificity seems similar to that of MMP-3, but catalytic activity toward type III, IV and V collagens is weaker (Murphy et al. 1991). Contrary to MMP-3, MMP-10 is not produced by fibroblasts, but is expressed in keratinocytes which in turn do not produce MMP-3 (Saarialho-Kere et al. 1994). MMP-10 seems to have an important role in skin wound healing and cellular migration, since it is primarily found at the front of the migrating epithelial 'tongue' (Madlener and Werner 1997) and has been observed in migrating enterocytes in inflammatory bowel disease (Salmela et al. 2004; Vaalamo et al. 1998). MMP-10 is, in vitro, capable of processing laminin-5, which may be an additional mechanism by which the enzyme enables cellular migration (Krampert et al. 2004). MMP-10 presence and activity at sites of resorption in developing bone have been demonstrated by histochemistry and casein in situ zymography and may play a role in remodeling events taking place during ossification (Bord et al. 1998).

\section{MMP-11}

The third human stromelysin is MMP-11, which was first described in 1990 in a breast carcinoma cDNA library (Basset et al. 1990). Although MMP-11 is often categorized as a stromelysin, it is very different from the other two proteases in this group. Production of MMP-11 is highest in fibroblasts and is particularly pronounced in remodeling tissues during the later stages of the process. MMP-11 has been associated with many physiological processes where ECM remodeling occurs, such as during embryonic development, the female reproductive cycle and wound healing. The $56-\mathrm{kDa}$ MMP-11 proenzyme is activated intracellularly by furin (Pei and Weiss 1995) or by paired basic amino acid cleaving enzyme-4 (PACE-4) (Bassi et al. 2000) and is secreted as a 47-kDa active protease. The physiological role of MMP-11 is unclear, but differs significantly from other MMPs. No major ECM proteins such as collagens, gelatin and fibronectin can be degraded by MMP-11, and contrary to many other MMPs, it exhibits an anti-apoptotic effect. The biological mechanism underlying this effect is not known, but probably involves proteolytic cleavage of yet uncharacterized protein substrates that promote cell survival (Matziari et al. 2007). Several possible substrates of MMP-11 have been identified, mainly protease inhibitors such as $\alpha_{1}$ proteinase inhibitor and $\alpha_{2}$ macroglobulin. MMP-11 further has a weak caseinolytic activity and has been shown to cleave insulin-like growth factor-binding protein-1 (IGF-BP-1) in a carcinoma cell line (Pei et al. 1994). Recent research has demonstrated that, although MMP-11 does not cleave many ECM proteins, degradation of type VI collagen is one of its physiological functions that is related to inhibition of adipogenesis (Motrescu et al. 2008).

The relatively narrow and peculiar substrate specificity of MMP-11 probably stems from a mutation that occurred in the highly conserved methionine turn. Whereas all other 
MMPs contain an MxP sequence in the Met turn, the proline is replaced by an alanine in MMP-11. This substitution has a profound effect on the structure of the S'1 selectivity pocket leading to greatly changed substrate specificity (Noel et al. 1995).

Although the physiological role of MMP-11 is still poorly understood, the involvement of this enzyme in especially the early stages of the process of tumor formation and metastasis has been thoroughly investigated [reviewed in Rio (2005)]. MMP-11 is rarely present in sarcoma tumors, but almost always expressed in carcinomas. An interesting observation is that MMP-11 is not produced by the malignant cells themselves, but by the surrounding mesenchymal cells. High levels of MMP-11 have predictive value for tumor aggressiveness and low survival rate. MMP-11 plays a role in early invasion of the surrounding tissue by tumor cells, a process that is dependent on the catalytic activity of the protease (Noel et al. 2000). This is surprising since MMP-11 is not capable of degradation of the major ECM constituents. Cancer cells are able to stimulate nearby fibroblasts to produce MMP11 , a process that is associated with modification of the invaded ECM to a stroma phenotype by desmoplasia (Mari et al. 1998). The anti-apoptotic effect of MMP-11 may play a role in establishment of the tumor and early survival. MMP-11-deficient tumors exhibit higher levels of apoptosis, and implantation of experimental tumors is lower in MMP-11 null mice (Boulay et al. 2001). Although development of primary tumors is favorably affected by high MMP-11 levels, the metastatic potential of MMP-11 expressing tumors seems to be lower. In experiments with MMP-11 null mice, the number and size of secondary tumors was greater than in wild-type mice implanted with similar sized tumors, indicating a protective effect of MMP-11 (Rio 2005).

\section{Membrane-anchored MMPs: membrane-type MMPs}

In addition to the soluble matrix metalloproteases, a small group of membrane-anchored MMPs has been described. The first member of this subfamily, MMP-14 or membrane type-1 MMP (MT1-MMP), was discovered in 1994 (Sato et al. 1994) and cloning experiments have since revealed the existence of five additional MT-MMPs. The domain structure of MMP-14 is very similar to that of soluble MMPs (see Fig. 1) with the characteristic zinc-binding catalytic domain, the prodomain in the inactive proenzyme and a linked hemopexin-like domain. Most MT-MMPs are membrane anchored by a single-pass transmembrane domain followed by an intracellular cytoplasmic tail that contains three putative phosphorylation sites and is presumed to be important for localizing the enzyme on the cell surface (Lehti et al. 2000). All MT-MMPs described contain the furin-like recognition site in their prodomain, allowing activation of the proenzyme by proteolytic removal of this domain by furin and other proprotein convertases (Yana and Weiss 2000).

\section{MMP-14}

MMP-14 is present at the cell surface as a 55-60 kDa active protease, but may be processed by autocatalysis into smaller species of $45 \mathrm{kDa}$ by proteolytic removal of the catalytic domain. This truncated form, which still contains the hemopexin-like domain, is assumed to play a role in autoregulation of MMP-14 catalytic activity (Toth et al. 2002). The substrate specificity of MMP-14 is well described in literature [reviewed in Barbolina and Stack (2008)]. The enzyme is capable of proteolytic degradation of type I, II and III collagens following the characteristic cleavage pathway used by collagenases (d'Ortho et al. 1997), a finding that was corroborated by knockout experiments that confirmed the role of MMP-14 as an important interstitial collagenase. MMP-14 null mice die within 3 weeks, showing severe developmental abnormalities related to deficiencies in ECM processing, such as dwarfism, skeletal dysplasia and defective vascularization (Holmbeck et al. 1999; Zhou et al. 2000). Expression of MMP-14 may be regulated by the interaction of migrating cells with a three-dimensional collagen matrix, which triggers clustering of cell surface integrins and lead to transcriptional activation of the MMP-14 promotor (Ellerbroek et al. 2001). Besides collagen, MMP-14 is capable of degradation of many other ECM components, such as fibronectin, vitronectin, tenascin, nidogen, aggrecan, fibrin, fibrinogen and laminin-5, leading to a possible stimulation of cellular migration as described above (Barbolina and Stack 2008). Although the major proteolytic function of MMP-14 lies in the cleavage of extracellular substrates, some studies indicate a role in intracellular proteolysis after incorporation and accumulation of active MMP-14 in the centrosomal compartment, where it could contribute to development of mitotic spindle changes by degradation of pericentrin (Golubkov et al. 2005a, b). This mechanism could give rise to a role for MMP-14 in malignant transformation of cells. Intracellular protein-protein interaction between MMP-14 and adenosine nucleotide translocator has been described and is independent of the catalytic activity of MMP-14. This observation may implicate MMP-14 as a player in the regulation of the changing energy metabolism in malignant cells during tumor formation and migration (Radichev et al. 2009). MMP-14 has further been identified as a cell surface sheddase and is capable of cleavage of many membrane-anchored proteins such as $\mathrm{E}$ - and $\mathrm{N}$ cadherin, integrins, hyaluronan receptor 
CD44, receptor activator of $\mathrm{NF}-\kappa \mathrm{B}$ ligand (RANKL) and several cell surface proteoglycans and their receptors (Barbolina and Stack 2008). Ongoing research by proteomics techniques has revealed an ever-growing array of possible endogenous substrates of MMP-14 (Niiya et al. 2009).

MMP-14 was originally identified as the extracellular protease responsible for activation of proMMP-2, and this process remains the best-described proteolytic function of the enzyme. In this process, one of the units of an MMP-14 dimer forms a trimeric complex with proMMP-2 and TIMP-2 at the cell surface leading to proteolytic removal of the propeptide of the proMMP-2 by the 'free' MMP-14 unit. Besides proMMP-2, also proMMP-13 (Knauper et al. 2002) and proMMP-8 (Holopainen et al. 2003) have been identified as possible targets for activation through this mechanism.

The role of MMP-14 in angiogenesis is well described and demonstrated by insufficient vascularization in knockout mice. MMP-14 is capable of degradation of the deposited fibrin matrix after vascular injury, effectively disrupting the repair mechanism and allowing endothelial cell invasion (Hiraoka et al. 1998). MMP-14 may also be involved in migration of endothelial cells into the ECM, by proteolytic degradation of extracellular matrix proteins and by processing of various adhesion molecules (Galvez et al. 2001). The formation and stabilization of the newly formed capillary tubes may also be dependent on MMP-14 activity, as demonstrated by impaired capillary formation in knockout models and RNA interference experiments (Robinet et al. 2005). Finally, MMP-14 is able to release vascular endothelial growth factor A (VEGF-A) by shedding, again promoting neovascularization (Sounni et al. 2004). MMP-14 together with MMP-15 may even be the determining factor in transforming cancer cells into the invasive phenotype, a process that is regulated by zincfinger proteins such as Snail-1 (Ota et al. 2009).

\section{MMP-15}

MT2-MMP (MMP-15) was first described in 1995 as the second member of the membrane-anchored MMP subfamily (Takino et al. 1995). MMP-15 is a ubiquitously expressed enzyme with largely overlapping substrate specificity with MMP-14 (d'Ortho et al. 1997). Although the physiological function of this protease is not as well described as for MMP-14, some studies have indicated a role in follicle rupture during ovulation (Ogiwara et al. 2005) and the generation of tubular structures during angiogenesis (Lafleur et al. 2002). MMP-15 has also antiapoptotic properties (Abraham et al. 2005). MMP-15 is capable of activating the MMP-2 proenzyme, but contrary to MMP-14 the activation mechanism is not dependent on the presence of TIMP-2, but rather on interaction with the hemopexin-like domain of MMP-2 (Morrison et al. 2001).

Involvement of MMP-15 in pathology is still unclear, but considering the similarity with MMP-14 a role in cancer is expected. Indeed, MMP-15 is present in many investigated tumors, such as glioblastoma (Zhang et al. 2005), non-small cell lung carcinoma (Atkinson et al. 2007), and ovarian (Davidson et al. 2001) and breast carcinoma (Ueno et al. 1997), and seems to correlate with tumor invasiveness (Zhang et al. 2005).

\section{MMP-16 and MMP-24}

The two latest additions to the membrane-spanning MMP family are MT3-MMP (MMP-16), first described in 1997 (Matsumoto et al. 1997), and MT5-MMP (MMP-24), first described in 1999 (Llano et al. 1999). These enzymes are still poorly described in literature. The crystal structure of MMP-16 has been elucidated, and shows extensive similarity to MMP-14 (Lang et al. 2004). MMP-16 activity is regulated by an autoproteolytic shedding process where a soluble form of the enzyme is released from the cell surface. The active enzyme shows high affinity to TIMP-3, as opposed to TIMP-1. Although originally anticipated to be a brain-specific enzyme (Pei 1999a), MMP-24 is possibly involved in remodeling events in endometrial lesions and endometriosis (Gaetje et al. 2007). Like the other MT-MMPs, both MMP-16 and MMP-24 are capable of activating proMMP-2 (Wang et al. 1999a; Zhao et al. 2004).

\section{MMP-17 and MMP-25}

The final two MT-MMPs are structurally different from the other four with respect to their interaction with the cell membrane. MT4-MMP (MMP-17) (Pendas et al. 1997) and MT6-MMP (MMP-25) (Pei 1999b) are linked to the cell membrane via a glycosyl-phosphatidyl-inositol (GPI) anchor, as opposed to containing a membrane-spanning domain. This anchor moiety is linked to the hemopexinlike domain by a 35-45 amino acid long hydrophilic linker, or stem. After production of the enzyme, this stem region is linked to a short hydrophobic tail, which is exchanged for a GPI anchor in the endoplasmic reticulum (Sohail et al. 2008). The stem region further contains two or three cysteine residues, which may have a function in formation of dimers or trimers, as demonstrated by the presence of $\sim 120$ and $\sim 180-\mathrm{kDa}$ protein species of MMP-25 that are dissociated into the mature $57-\mathrm{kDa}$ form of the enzyme under reducing conditions (Sun et al. 2007). The GPI anchor gives these enzymes the possibility of interaction with lipid raft microstructures and may be involved in internalization and recycling of the enzymes (Sohail et al. 2008). The TIMP-inhibition profile of the GPI-anchored 
MT-MMPs is different from the membrane-anchored MT-MMPs. While the latter are relatively resistant to inhibition by TIMP-1 due to incompatibility of the $\mathrm{Thr}^{98}$ residue with the S'1 selectivity pocket, MMP-17 and MMP-25 are effectively inhibited by TIMP-1, as well as by TIMP-2 and TIMP-3 (English et al. 2001; Wang et al. 1999b). GPI-anchored MT-MMPs can be shed from various cells in exosomes, possibly leading to paracrine transfer to other cells (Itoh et al. 1999).

Both MMP-17 and MMP-25 are capable of degrading ECM proteins, albeit MMP-17 in a limited fashion with cleavage demonstrated for gelatin, fibrin and fibrinogen. MMP-25 can cleave a wider range of ECM constituents including fibronectin, type IV collagen and proteoglycans (Kang et al. 2001). In vitro experiments have revealed a multitude of possible substrates (including TNF alpha, indicating sheddase activity), but the physiological relevance is unclear [reviewed in Sohail et al. (2008)]. Interestingly, MMP-17 is not able to activate proMMP-2 even in vitro, making this the only MT-MMP that lacks this trait (English et al. 2000). MMP-25 does activate proMMP-2, but generates a different form of the active enzyme than the other MT-MMPs, indicating that the interaction between MMP-2 and MMP-25 is different (Nie and Pei 2003). This activation mechanism is possibly dependent on the tight junction protein claudin- 5 , since cells that do not produce this protein are incapable of proMMP-2 activation by MMP-25 (Miyamori et al. 2001). MMP-17 has been described as an activator of the aggrecanase ADAMTS-4 (Gao et al. 2004).

Both GPI-anchored MT-MMPs are highly expressed in a wide variety of cancer cells ranging from breast carcinoma to glioma and colon cancers [reviewed in Sohail et al. (2008)], but the clinical relevance of the presence of these proteins in malignant cells is not yet clear.

\section{Soluble MMPs: matrilysins}

\section{MMP-7}

MMP-7 (matrilysin) was originally described as PUMP-1 (putative uterine metalloprotease-1) in 1988, and was long considered a third member of the stromelysin family (MMP-11 was not yet known), although it appeared only distantly related to the other stromelysins (Muller et al. 1988). The pump- 1 gene identified from rat tumor cDNA cloning experiments was confirmed to code for a secreted metalloprotease in rat uterus (Woessner and Taplin 1988), and later dubbed MMP-7. The mmp-7 gene contains a AP-1 promotor region, making it sensitive to upregulation by cytokines and growth factors (Gaire et al. 1994). MMP-7 is the smallest human MMP (28-kDa proenzyme, 19-kDa mature active form), since it lacks the C-terminal hemopexin-like domain. This 'minimal domain structure' means that the activated enzyme comprises only the zinc-binding catalytic domain and results in an inability of MMP-7 to degrade intact collagens, again demonstrating the importance of the hemopexin-like domain in substrate recognition (Quantin et al. 1989). MMP-7 is, however, capable of degrading a wide array of other ECM components such as gelatin, fibronectin, laminin and elastin. MMP-7 is capable of cleaving the prodomain of the gelatinases MMP-2 and -9 (Wilson and Matrisian 1996), but its relevance under physiological conditions seems debatable considering the alternative, well-described activation pathway of proMMP-2. Finally, MMP-7 is a possible sheddase, with potential to liberate $\mathrm{TNF} \alpha$, Fas ligand, heparin-binding epidermal growth factor (HB-EGF), E-cadherin and $\beta 4$-integrin (Ii et al. 2006).

The originally described biological function of MMP-7 is the involvement in involution of the endometrium after pregnancy, but as later discovered, a unique function of MMP-7 seems to be its role in innate immunity. MMP-7 knockout mice exhibit decreased resistance to bacterial gastrointestinal infection and show decreased clearance of E. coli from the small intestine. MMP-7 is constitutively produced in the mucosal epithelium and may exert its function in mice by cleavage of pro- $\alpha$-defensins yielding peptides with antibacterial properties. Co-localization of MMP-7 and pro- $\alpha$-defensins in specialized epithelial Paneth cells seems to confirm this function (Wilson et al. 1999). The role in mucosal host defense is further supported by the finding that exposure of cultured mucosal epithelial tissue or cells to pathogenic bacteria such as E. coli or Pseudomonas aeruginosa causes an increased production of MMP-7, and that germ-free bred mice show no expression of MMP-7 in the unchallenged gastro-intestinal tract (Lopez-Boado et al. 2001). The strong induction of MMP-7 by bacterial challenge is an epithelium-specific function, since it does not occur in other cell types expressing MMP-7, and is exclusive for MMP-7 since no other MMPs are upregulated (Parks and Shapiro 2001).

MMP-7 seems to be important in wound repair, since MMP-7 null mice show severe defects in epithelial wound healing which is probably due to a disrupted reepithelialization (Dunsmore et al. 1998). MMP-7 further enables migration of neutrophils through the epithelium during inflammation, since MMP-7 null mice show accumulation of neutrophils in the interstitium without them crossing over into the epithelium ( $\mathrm{Li}$ et al. 2002). The mechanism underlying this effect is probably the creation of a chemotactic gradient for neutrophils by cleavage of the proteoglycan syndecan-1 at the epithelial cell surface, causing liberation of the syndecan-bound chemokine $\mathrm{KC}$ that is produced by the epithelial cells after injury. 
The role of MMP-7 in cancer has been well described. MMP-7 seems to occupy a unique place among MMPs with respect to cancer association, since it is one of the few MMPs that is actually produced by cancerous cells themselves, as opposed to the stroma-derived MMPs that are produced under stimulation by malignant cells (Ii et al. 2006). As with other MMPs, MMP-7 has been identified in a wide range of tumors, and correlates with the aggressiveness of the tumor. In a malignant state, the activation of MMP-2 and -9 by MMP-7 may have an important function, and lead to increased invasiveness (Wang et al. 2005, 2006). MMP-7, like MMP-3 may further promote tumor invasion by shedding of E-cadherin, leading to decreased cellular adhesion. Tumor growth is likely associated with MMP-7 sheddase activity, since the release of soluble HBEGF by MMP-7 promotes cellular proliferation ( $\mathrm{Yu}$ et al. 2002). MMP-7 is further capable of cleaving all six members of the insulin-like growth factor-binding protein (IGF-BP) family, leading to increased availability of free IGF, which again promotes cancer cell growth and survival (Nakamura et al. 2005). The activation of ADAM-28 is also attributed to MMP-7 (Mochizuki et al. 2004), leading to increased degradation of IGF-BP3.

\section{MMP-26}

Recently, a novel matrilysin-like enzyme was identified in an endometrial tumor and named MMP-26 (matrilysin-2, endometase) (de Coignac et al. 2000; Uria and Lopez-Otin 2000). Like MMP-7, this is a minimal domain MMP missing the hemopexin-like C-terminus. This protease seems to have a more limited substrate specificity compared to MMP-7 and cannot degrade collagens, laminin and elastin (Park et al. 2000). MMP-26 is unique among MMPs, since it is the only MMP described so far that does not have a functional cysteine switch mechanism to maintain the proenzyme in its latent conformation. Loss of the cysteine switch is attributed to the presence of a histidine residue $\mathrm{N}$-terminal to the cysteine, a feature that is only observed in MMP-26 (Marchenko et al. 2001; Marchenko and Strongin 2001). Basal expression of MMP-26 is low except in endometrium, but is increased in many carcinoma cell lines (Marchenko et al. 2001). The physiological function of MMP-26 remains to be elucidated.

\section{Soluble MMPs: MMP-12 (macrophage metalloelastase)}

MMP-12 was first described in 1981 (Banda and Werb 1981) as murine metalloelastase and later identified as a member of the MMP family (Shapiro et al. 1992). In 1993, a human ortholog was found (Shapiro et al. 1993). MMP-12 was identified as an elastolytic metalloprotease produced by alveolar macrophages, which led to the trivial name (murine) macrophage metalloelastase (MME) or human macrophage elastase (HME). MMP-12 is expressed as a $54-\mathrm{kDa}$ inactive proenzyme and is activated to a $45-\mathrm{kDa}$ active enzyme by removal of the propeptide sequence. The mature enzyme can be further truncated to a $22-\mathrm{kDa}$ active form on C-terminal processing mediated by serine proteases or through autocatalytic cleavage (Shapiro et al. 1993). Autocatalytic removal of the C-terminal domain is possible in many other MMPs, but occurs very slowly in contrast to MMP-12, which is readily processed to the smaller form. Expression of MMP-12 is limited to macrophages and is not observed in blood monocytes. As the name reveals, a major substrate for MMP-12 is elastin, but MMP-12 is capable of degrading other ECM constituents (but not gelatin) (Banda et al. 1983) and many nonmatrix proteins in vitro (Chandler et al. 1996).

MMP-12 null mice show normal development in the absence of inflammatory stress, but litter size is smaller, presumably due to abnormalities of the placenta during gestation. Macrophages obtained from knockout mice retain only a small fraction of their elastolytic activity, indicating that MMP-12 is indeed the most important elastin-degrading enzyme (in mice). MMP-12 is necessary for the penetration of macrophages through the basement membrane, as demonstrated by a complete inhibition of macrophage migration from MMP-12 null mice both in vitro and in vivo (Shipley et al. 1996).

MMP-12 seems to play an intriguing role in cancer, which is different from other MMPs. MMP-12 is the primary protease responsible for proteolytic liberation of angiostatin from plasminogen. Angiostatin is a $38-\mathrm{kDa}$ protein with anti-angiogenic properties due to the selective inhibition of endothelial cell proliferation. MMP-2 and -9 are also capable of degradation of plasminogen in vitro, but were found to make only a minor or no contribution to the production of angiostatin in an animal model (Dong et al. 1997; Houghton et al. 2006). This is another example of a protective effect of MMP activity in tumor genesis, an indication that knowledge of the actual biochemical mechanism of the involvement of a protease in disease is indispensable and cannot be replaced by mere association of expression levels in tumors.

Since human MMP-12 was first cloned from alveolar macrophages, it is not surprising that the role of MMP-12 in lung disease has been extensively studied. The involvement of MMP-12 in fibrotic processes in the lung is well established, but studies concerning the role of MMP-12 in emphysema are diffuse due to species differences between murine models and humans. In humans, it was reported that MMP-12 is not upregulated in macrophages of patients with emphysema compared to controls, but rather that macrophage-derived MMP-9 and 
MMP-1 are upregulated (Finlay et al. 1997). MMP-12, on the other hand, was shown to be an absolute requirement for the development of emphysema after cigarette smoke exposure in a knockout animal model (Hautamaki et al. 1997; Matute-Bello et al. 2007, 2008). The interspecies difference may have caused bias with respect to the importance of MMP-12 since, although the failure of MMP-12 null mice to develop emphysema upon smoke exposure makes a more compelling point than determination of expression levels, MMP-12 seems to be the major MMP in murine macrophages, while human macrophages produce several MMPs (Parks and Shapiro 2001). Evidence for a role of MMP-12 in lung function is based on a polymorphism in the MMP-12 gene that has been described to have predictive value for lung function decline in COPD (Joos et al. 2002), a finding that was recently corroborated in a large association study between a single nucleotide polymorphism (SNP) in the MMP-12 promotor, which decreases MMP-12 expression, and a protective effect against lung function decline in asthma and COPD patients (Hunninghake et al. 2009). Elevated MMP-12 levels have been measured in induced sputum of COPD patients (Demedts et al. 2006), while a recent study has found only a slight increase of MMP-12 in stage 0 of the disease (Ilumets et al. 2007). Proteolytic fragments of elastin have been implicated as chemotactic factors in macrophage recruitment (Senior et al. 1980), giving a possible explanation for an early role of MMP-12 in emphysema development, with severe tissue destruction at later stages being mainly caused by other macrophage-derived proteases.

\section{Conclusions}

Matrix metalloproteases (MMPs) form a large family of enzymes with broad substrate specificity. While their initial role was mainly ascribed to turnover of the extracellular matrix, this view must likely be revised based on recent, more comprehensive studies. MMPs are involved in a delicate balance between proteolytic and anti-proteolytic activity to confine them in time and space. When this balance is disturbed, many disease phenotypes are observed ranging from tissue destruction in chronic inflammatory conditions, such as rheumatoid arthritis and COPD, to cancer metastasis and neurological disorders. The fact that MMPs degrade proteins into fragments with often new, completely different biological activities, supports the view of protein species.

Open Access This article is distributed under the terms of the Creative Commons Attribution Noncommercial License which permits any noncommercial use, distribution, and reproduction in any medium, provided the original author(s) and source are credited.

\section{References}

Abraham R, Schafer J, Rothe M, Bange J, Knyazev P, Ullrich A (2005) Identification of MMP-15 as an anti-apoptotic factor in cancer cells. J Biol Chem 280:34123-34132

Alge-Priglinger CS, Kreutzer T, Obholzer K, Wolf A, Mempel M, Kernt M, Kampik A, Priglinger SG (2009) Oxidative stressmediated induction of MMP-1 and MMP-3 in human RPE cells. Invest Ophthalmol Vis Sci 50:5495-5503

Arza B, Hoylaerts MF, Felez J, Collen D, Lijnen HR (2000) Prostromelysin-1 (proMMP-3) stimulates plasminogen activation by tissue-type plasminogen activator. Eur $\mathrm{J}$ Biochem 267:6378-6384

Atkinson JM, Pennington CJ, Martin SW, Anikin VA, Mearns AJ, Loadman PM, Edwards DR, Gill JH (2007) Membrane type matrix metalloproteinases (MMPs) show differential expression in non-small cell lung cancer (NSCLC) compared to normal lung: correlation of MMP-14 mRNA expression and proteolytic activity. Eur J Cancer 43:1764-1771

Balbin M, Fueyo A, Knauper V, Pendas AM, Lopez JM, Jimenez MG, Murphy G, Lopez-Otin C (1998) Collagenase 2 (MMP-8) expression in murine tissue-remodeling processes. Analysis of its potential role in postpartum involution of the uterus. J Biol Chem 273:23959-23968

Balbin M, Pendas AM, Uria JA, Jimenez MG, Freije JP, Lopez-Otin C (1999) Expression and regulation of collagenase-3 (MMP-13) in human malignant tumors. APMIS 107:45-53

Banda MJ, Werb Z (1981) Mouse macrophage elastase. Purification and characterization as a metalloproteinase. Biochem J 193:589-605

Banda MJ, Clark EJ, Werb Z (1983) Selective proteolysis of immunoglobulins by mouse macrophage elastase. J Exp Med 157:1184 1196

Barbolina MV, Stack MS (2008) Membrane type 1-matrix metalloproteinase: substrate diversity in pericellular proteolysis. Semin Cell Dev Biol 19:24-33

Barksby HE, Milner JM, Patterson AM, Peake NJ, Hui W, Robson T, Lakey R, Middleton J, Cawston TE, Richards CD, Rowan AD (2006) Matrix metalloproteinase 10 promotion of collagenolysis via procollagenase activation: implications for cartilage degradation in arthritis. Arthritis Rheum 54:3244-3253

Barmina OY, Walling HW, Fiacco GJ, Freije JM, Lopez-Otin C, Jeffrey JJ, Partridge NC (1999) Collagenase-3 binds to a specific receptor and requires the low density lipoprotein receptor-related protein for internalization. J Biol Chem 274:30087-30093

Baruch RR, Melinscak H, Lo J, Liu Y, Yeung O, Hurta RA (2001) Altered matrix metalloproteinase expression associated with oncogene-mediated cellular transformation and metastasis formation. Cell Biol Int 25:411-420

Basset P, Bellocq JP, Wolf C, Stoll I, Hutin P, Limacher JM, Podhajcer OL, Chenard MP, Rio MC, Chambon P (1990) A novel metalloproteinase gene specifically expressed in stromal cells of breast carcinomas. Nature 348:699-704

Bassi DE, Mahloogi H, Klein-Szanto AJ (2000) The proprotein convertases furin and PACE4 play a significant role in tumor progression. Mol Carcinog 28:63-69

Benbow U, Schoenermark MP, Mitchell TI, Rutter JL, Shimokawa K, Nagase H, Brinckerhoff CE (1999) A novel host/tumor cell interaction activates matrix metalloproteinase 1 and mediates invasion through type I collagen. J Biol Chem 274:25371-25378

Bergers G, Brekken R, McMahon G, Vu TH, Itoh T, Tamaki K, Tanzawa K, Thorpe P, Itohara S, Werb Z, Hanahan D (2000) Matrix metalloproteinase- 9 triggers the angiogenic switch during carcinogenesis. Nat Cell Biol 2:737-744

Biswas C, Zhang Y, DeCastro R, Guo H, Nakamura T, Kataoka H, Nabeshima K (1995) The human tumor cell-derived collagenase 
stimulatory factor (renamed EMMPRIN) is a member of the immunoglobulin superfamily. Cancer Res 55:434-439

Bjorklund M, Koivunen E (2005) Gelatinase-mediated migration and invasion of cancer cells. Biochim Biophys Acta 1755:37-69

Bode W (1995) A helping hand for collagenases: the haemopexin-like domain. Structure 3:527-530

Bode W, Gomis-Ruth FX, Huber R, Zwilling R, Stocker W (1992) Structure of astacin and implications for activation of astacins and zinc-ligation of collagenases. Nature 358:164-167

Bode W, Gomis-Ruth FX, Stockler W (1993) Astacins, serralysins, snake venom and matrix metalloproteinases exhibit identical zinc-binding environments (HEXXHXXGXXH and Met-turn) and topologies and should be grouped into a common family, the 'metzincins'. FEBS Lett 331:134-140

Bode W, Fernandez-Catalan C, Tschesche H, Grams F, Nagase H, Maskos K (1999) Structural properties of matrix metalloproteinases. Cell Mol Life Sci 55:639-652

Bord S, Horner A, Hembry RM, Compston JE (1998) Stromelysin-1 (MMP-3) and stromelysin-2 (MMP-10) expression in developing human bone: potential roles in skeletal development. Bone 23:7-12

Boulay A, Masson R, Chenard MP, El Fahime M, Cassard L, Bellocq JP, Sautes-Fridman C, Basset P, Rio MC (2001) High cancer cell death in syngeneic tumors developed in host mice deficient for the stromelysin-3 matrix metalloproteinase. Cancer Res 61:21892193

Breathnach R, Matrisian LM, Gesnel MC, Staub A, Leroy P (1987) Sequences coding for part of oncogene-induced transin are highly conserved in a related rat gene. Nucleic Acids Res 15:1139-1151

Brinckerhoff CE, Sirum-Connolly KL, Karmilowicz MJ, Auble DT (1992) Expression of stromelysin and stromelysin-2 in rabbit and human fibroblasts. Matrix Suppl 1:165-175

Brinckerhoff CE, Rutter JL, Benbow U (2000) Interstitial collagenases as markers of tumor progression. Clin Cancer Res 6:48234830

Browner MF, Smith WW, Castelhano AL (1995) Matrilysin-inhibitor complexes: common themes among metalloproteases. Biochemistry 34:6602-6610

Burrage PS, Mix KS, Brinckerhoff CE (2006) Matrix metalloproteinases: role in arthritis. Front Biosci 11:529-543

Butler GS, Overall CM (2009) Updated biological roles for matrix metalloproteinases and new "intracellular" substrates revealed by degradomics. Biochemistry 48:10830-10845

Butler PE, McKay MJ, Bond JS (1987) Characterization of meprin, a membrane-bound metalloendopeptidase from mouse kidney. Biochem J 241:229-235

Cao J, Rehemtulla A, Bahou W, Zucker S (1996) Membrane type matrix metalloproteinase 1 activates pro-gelatinase A without furin cleavage of the N-terminal domain. J Biol Chem 271:3017430180

Chakrabarti S, Patel KD (2005) Matrix metalloproteinase-2 (MMP-2) and MMP-9 in pulmonary pathology. Exp Lung Res 31:599-621

Chandler S, Cossins J, Lury J, Wells G (1996) Macrophage metalloelastase degrades matrix and myelin proteins and processes a tumour necrosis factor-alpha fusion protein. Biochem Biophys Res Commun 228:421-429

Chernov AV, Sounni NE, Remacle AG, Strongin AY (2009) Epigenetic control of the invasion-promoting MT1-MMP/ MMP-2/TIMP-2 axis in cancer cells. J Biol Chem 284:1272712734

Chin JR, Murphy G, Werb Z (1985) Stromelysin, a connective tissuedegrading metalloendopeptidase secreted by stimulated rabbit synovial fibroblasts in parallel with collagenase. Biosynthesis, isolation, characterization, and substrates. J Biol Chem 260: 12367-12376
Corry DB, Rishi K, Kanellis J, Kiss A, Song Lz LZ, Xu J, Feng L, Werb Z, Kheradmand F (2002) Decreased allergic lung inflammatory cell egression and increased susceptibility to asphyxiation in MMP2-deficiency. Nat Immunol 3:347-353

Crocker SJ, Pagenstecher A, Campbell IL (2004) The TIMPs tango with MMPs and more in the central nervous system. J Neurosci Res 75:1-11

D'Armiento J, Dalal SS, Okada Y, Berg RA, Chada K (1992) Collagenase expression in the lungs of transgenic mice causes pulmonary emphysema. Cell 71:955-961

D'Armiento J, DiColandrea T, Dalal SS, Okada Y, Huang MT, Conney AH, Chada K (1995) Collagenase expression in transgenic mouse skin causes hyperkeratosis and acanthosis and increases susceptibility to tumorigenesis. Mol Cell Biol 15:5732-5739

D’Ortho MP, Will H, Atkinson S, Butler G, Messent A, Gavrilovic J, Smith B, Timpl R, Zardi L, Murphy G (1997) Membrane-type matrix metalloproteinases 1 and 2 exhibit broad-spectrum proteolytic capacities comparable to many matrix metalloproteinases. Eur J Biochem 250:751-757

Dahlen B, Shute J, Howarth P (1999) Immunohistochemical localisation of the matrix metalloproteinases MMP-3 and MMP-9 within the airways in asthma. Thorax 54:590-596

Davidson B, Goldberg I, Berner A, Nesland JM, Givant-Horwitz V, Bryne M, Risberg B, Kristensen GB, Trope CG, Kopolovic J, Reich R (2001) Expression of membrane-type 1, 2, and 3 matrix metalloproteinases messenger RNA in ovarian carcinoma cells in serous effusions. Am J Clin Pathol 115:517-524

de Coignac AB, Elson G, Delneste Y, Magistrelli G, Jeannin P, Aubry JP, Berthier O, Schmitt D, Bonnefoy JY, Gauchat JF (2000) Cloning of MMP-26. A novel matrilysin-like proteinase. Eur J Biochem 267:3323-3329

Dean RA, Overall CM (2007) Proteomics discovery of metalloproteinase substrates in the cellular context by iTRAQ labeling reveals a diverse MMP-2 substrate degradome. Mol Cell Proteomics 6:611623

Dean RA, Butler GS, Hamma-Kourbali Y, Delbe J, Brigstock DR, Courty J, Overall CM (2007) Identification of candidate angiogenic inhibitors processed by matrix metalloproteinase 2 (MMP-2) in cell-based proteomic screens: disruption of vascular endothelial growth factor (VEGF)/heparin affin regulatory peptide (pleiotrophin) and VEGF/connective tissue growth factor angiogenic inhibitory complexes by MMP-2 proteolysis. Mol Cell Biol 27:8454-8465

Demedts IK, Morel-Montero A, Lebecque S, Pacheco Y, Cataldo D, Joos GF, Pauwels RA, Brusselle GG (2006) Elevated MMP-12 protein levels in induced sputum from patients with COPD. Thorax 61:196-201

Deryugina EI, Ratnikov B, Monosov E, Postnova TI, DiScipio R, Smith JW, Strongin AY (2001) MT1-MMP initiates activation of pro-MMP-2 and integrin alphavbeta3 promotes maturation of MMP-2 in breast carcinoma cells. Exp Cell Res 263:209-223

Desrochers PE, Mookhtiar K, Van Wart HE, Hasty KA, Weiss SJ (1992) Proteolytic inactivation of alpha 1-proteinase inhibitor and alpha 1-antichymotrypsin by oxidatively activated human neutrophil metalloproteinases. J Biol Chem 267:5005-5012

Devarajan P, Johnston JJ, Ginsberg SS, Van Wart HE, Berliner N (1992) Structure and expression of neutrophil gelatinase cDNA. Identity with type IV collagenase from HT1080 cells. J Biol Chem 267:25228-25232

Dong Z, Kumar R, Yang X, Fidler IJ (1997) Macrophage-derived metalloelastase is responsible for the generation of angiostatin in Lewis lung carcinoma. Cell 88:801-810

Dozier S, Escobar GP, Lindsey ML (2006) Matrix metalloproteinase (MMP)-7 activates MMP-8 but not MMP-13. Med Chem 2:523-526 
Dubois B, Arnold B, Opdenakker G (2000) Gelatinase B deficiency impairs reproduction. J Clin Invest 106:627-628

Dunsmore SE, Saarialho-Kere UK, Roby JD, Wilson CL, Matrisian LM, Welgus HG, Parks WC (1998) Matrilysin expression and function in airway epithelium. J Clin Invest 102:1321-1331

Ellerbroek SM, Wu YI, Overall CM, Stack MS (2001) Functional interplay between type I collagen and cell surface matrix metalloproteinase activity. J Biol Chem 276:24833-24842

English WR, Puente XS, Freije JM, Knauper V, Amour A, Merryweather A, Lopez-Otin C, Murphy G (2000) Membrane type 4 matrix metalloproteinase (MMP17) has tumor necrosis factor-alpha convertase activity but does not activate pro-MMP2. J Biol Chem 275:14046-14055

English WR, Velasco G, Stracke JO, Knauper V, Murphy G (2001) Catalytic activities of membrane-type 6 matrix metalloproteinase (MMP25). FEBS Lett 491:137-142

Engsig MT, Chen QJ, Vu TH, Pedersen AC, Therkidsen B, Lund LR, Henriksen K, Lenhard T, Foged NT, Werb Z, Delaisse JM (2000) Matrix metalloproteinase 9 and vascular endothelial growth factor are essential for osteoclast recruitment into developing long bones. J Cell Biol 151:879-889

Esparza J, Kruse M, Lee J, Michaud M, Madri JA (2004) MMP-2 null mice exhibit an early onset and severe experimental autoimmune encephalomyelitis due to an increase in MMP-9 expression and activity. FASEB J 18:1682-1691

Ezhilarasan R, Jadhav U, Mohanam I, Rao JS, Gujrati M, Mohanam S (2009) The hemopexin domain of MMP-9 inhibits angiogenesis and retards the growth of intracranial glioblastoma xenograft in nude mice. Int J Cancer 124:306-315

Finlay GA, O'Driscoll LR, Russell KJ, D'Arcy EM, Masterson JB, FitzGerald MX, O'Connor CM (1997) Matrix metalloproteinase expression and production by alveolar macrophages in emphysema. Am J Respir Crit Care Med 156:240-247

Forsyth PA, Wong H, Laing TD, Rewcastle NB, Morris DG, Muzik H, Leco KJ, Johnston RN, Brasher PM, Sutherland G, Edwards DR (1999) Gelatinase-A (MMP-2), gelatinase-B (MMP-9) and membrane type matrix metalloproteinase-1 (MT1-MMP) are involved in different aspects of the pathophysiology of malignant gliomas. Br J Cancer 79:1828-1835

Fray MJ, Dickinson RP, Huggins JP, Occleston NL (2003) A potent, selective inhibitor of matrix metalloproteinase-3 for the topical treatment of chronic dermal ulcers. J Med Chem 46:3514-3525

Freije JM, Diez-Itza I, Balbin M, Sanchez LM, Blasco R, Tolivia J, Lopez-Otin C (1994) Molecular cloning and expression of collagenase-3, a novel human matrix metalloproteinase produced by breast carcinomas. J Biol Chem 269:16766-16773

Gaetje R, Holtrich U, Engels K, Kourtis K, Cikrit E, Kissler S, Rody A, Karn T, Kaufmann M (2007) Expression of membrane-type 5 matrix metalloproteinase in human endometrium and endometriosis. Gynecol Endocrinol 23:567-573

Gaire M, Magbanua Z, McDonnell S, McNeil L, Lovett DH, Matrisian LM (1994) Structure and expression of the human gene for the matrix metalloproteinase matrilysin. J Biol Chem 269:2032-2040

Galvez BG, Matias-Roman S, Albar JP, Sanchez-Madrid F, Arroyo AG (2001) Membrane type 1-matrix metalloproteinase is activated during migration of human endothelial cells and modulates endothelial motility and matrix remodeling. J Biol Chem 276:37491-37500

Gao G, Plaas A, Thompson VP, Jin S, Zuo F, Sandy JD (2004) ADAMTS4 (aggrecanase-1) activation on the cell surface involves C-terminal cleavage by glycosylphosphatidyl inositolanchored membrane type 4-matrix metalloproteinase and binding of the activated proteinase to chondroitin sulfate and heparan sulfate on syndecan-1. J Biol Chem 279:10042-10051

Golubkov VS, Boyd S, Savinov AY, Chekanov AV, Osterman AL, Remacle A, Rozanov DV, Doxsey SJ, Strongin AY (2005a)
Membrane type-1 matrix metalloproteinase (MT1-MMP) exhibits an important intracellular cleavage function and causes chromosome instability. J Biol Chem 280:25079-25086

Golubkov VS, Chekanov AV, Doxsey SJ, Strongin AY (2005b) Centrosomal pericentrin is a direct cleavage target of membrane type-1 matrix metalloproteinase in humans but not in mice: potential implications for tumorigenesis. $\mathrm{J}$ Biol Chem 280:42237-42241

Gomez DE, Alonso DF, Yoshiji H, Thorgeirsson UP (1997) Tissue inhibitors of metalloproteinases: structure, regulation and biological functions. Eur J Cell Biol 74:111-122

Green MJ, Gough AK, Devlin J, Smith J, Astin P, Taylor D, Emery P (2003) Serum MMP-3 and MMP-1 and progression of joint damage in early rheumatoid arthritis. Rheumatology (Oxford) 42:83-88

Gross J, Lapiere CM (1962) Collagenolytic activity in amphibian tissues: a tissue culture assay. Proc Natl Acad Sci USA 48:1014-1022

Gruber BL, Marchese MJ, Suzuki K, Schwartz LB, Okada Y, Nagase H, Ramamurthy NS (1989) Synovial procollagenase activation by human mast cell tryptase dependence upon matrix metalloproteinase 3 activation. J Clin Invest 84:1657-1662

Gutierrez-Fernandez A, Fueyo A, Folgueras AR, Garabaya C, Pennington CJ, Pilgrim S, Edwards DR, Holliday DL, Jones JL, Span PN, Sweep FC, Puente XS, Lopez-Otin C (2008) Matrix metalloproteinase- 8 functions as a metastasis suppressor through modulation of tumor cell adhesion and invasion. Cancer Res 68:2755-2763

Hasty KA, Pourmotabbed TF, Goldberg GI, Thompson JP, Spinella DG, Stevens RM, Mainardi CL (1990) Human neutrophil collagenase. A distinct gene product with homology to other matrix metalloproteinases. J Biol Chem 265:11421-11424

Hautamaki RD, Kobayashi DK, Senior RM, Shapiro SD (1997) Requirement for macrophage elastase for cigarette smokeinduced emphysema in mice. Science 277:2002-2004

Heim-Riether A, Taylor SJ, Liang S, Gao DA, Xiong Z, Michael AE, Collins BK, Farmer BT, Haverty K, Hill-Drzewi M, Junker HD, Mariana MS, Moss N, Neumann T, Proudfoot JR, Keenan LS, Sekul R, Zhang Q, Li J, Farrow NA (2009) Improving potency and selectivity of a new class of non-Zn-chelating MMP-13 inhibitors. Bioorg Med Chem Lett 19:5321-5324

Herman MP, Sukhova GK, Libby P, Gerdes N, Tang N, Horton DB, Kilbride M, Breitbart RE, Chun M, Schonbeck U (2001) Expression of neutrophil collagenase (matrix metalloproteinase8) in human atheroma: a novel collagenolytic pathway suggested by transcriptional profiling. Circulation 104:1899-1904

Hiraoka N, Allen E, Apel IJ, Gyetko MR, Weiss SJ (1998) Matrix metalloproteinases regulate neovascularization by acting as pericellular fibrinolysins. Cell 95:365-377

Holmbeck K, Bianco P, Caterina J, Yamada S, Kromer M, Kuznetsov SA, Mankani M, Robey PG, Poole AR, Pidoux I, Ward JM, Birkedal-Hansen H (1999) MT1-MMP-deficient mice develop dwarfism, osteopenia, arthritis, and connective tissue disease due to inadequate collagen turnover. Cell 99:81-92

Holopainen JM, Moilanen JA, Sorsa T, Kivela-Rajamaki M, Tervahartiala T, Vesaluoma MH, Tervo TM (2003) Activation of matrix metalloproteinase- 8 by membrane type 1-MMP and their expression in human tears after photorefractive keratectomy. Invest Ophthalmol Vis Sci 44:2550-2556

Houghton AM, Grisolano JL, Baumann ML, Kobayashi DK, Hautamaki RD, Nehring LC, Cornelius LA, Shapiro SD (2006) Macrophage elastase (matrix metalloproteinase-12) suppresses growth of lung metastases. Cancer Res 66:6149-6155

Hu Y, Xiang JS, DiGrandi MJ, Du X, Ipek M, Laakso LM, Li J, Li W, Rush TS, Schmid J, Skotnicki JS, Tam S, Thomason JR, Wang Q, Levin JI (2005) Potent, selective, and orally bioavailable matrix metalloproteinase-13 inhibitors for the treatment of osteoarthritis. Bioorg Med Chem 13:6629-6644 
Hunninghake GM, Cho MH, Tesfaigzi Y, Soto-Quiros ME, Avila L, Lasky-Su J, Stidley C, Melen E, Soderhall C, Hallberg J, Kull I, Kere J, Svartengren M, Pershagen G, Wickman M, Lange C, Demeo DL, Hersh CP, Klanderman BJ, Raby BA, Sparrow D, Shapiro SD, Silverman EK, Litonjua AA, Weiss ST, Celedon JC (2009) MMP12, lung function, and COPD in high-risk populations. N Engl J Med 361:2599-2608

Iba K, Albrechtsen R, Gilpin B, Frohlich C, Loechel F, Zolkiewska A, Ishiguro K, Kojima T, Liu W, Langford JK, Sanderson RD, Brakebusch C, Fassler R, Wewer UM (2000) The cysteine-rich domain of human ADAM 12 supports cell adhesion through syndecans and triggers signaling events that lead to betal integrin-dependent cell spreading. J Cell Biol 149:1143-1156

Ii M, Yamamoto H, Adachi Y, Maruyama Y, Shinomura Y (2006) Role of matrix metalloproteinase-7 (matrilysin) in human cancer invasion, apoptosis, growth, and angiogenesis. Exp Biol Med (Maywood) 231:20-27

Ilumets H, Rytila P, Demedts I, Brusselle GG, Sovijarvi A, Myllarniemi M, Sorsa T, Kinnula VL (2007) Matrix metalloproteinases $-8,-9$ and -12 in smokers and patients with stage 0 COPD. Int J Chron Obstruct Pulmon Dis 2:369-379

Imai K, Dalal SS, Hambor J, Mitchell P, Okada Y, Horton WC, D'Armiento J (2007) Bone growth retardation in mouse embryos expressing human collagenase 1. Am J Physiol Cell Physiol 293:C1209-C1215

Iredale JP, Benyon RC, Pickering J, McCullen M, Northrop M, Pawley S, Hovell C, Arthur MJ (1998) Mechanisms of spontaneous resolution of rat liver fibrosis. Hepatic stellate cell apoptosis and reduced hepatic expression of metalloproteinase inhibitors. J Clin Invest 102:538-549

Itoh T, Tanioka M, Yoshida H, Yoshioka T, Nishimoto H, Itohara S (1998) Reduced angiogenesis and tumor progression in gelatinase A-deficient mice. Cancer Res 58:1048-1051

Itoh Y, Kajita M, Kinoh H, Mori H, Okada A, Seiki M (1999) Membrane type 4 matrix metalloproteinase (MT4-MMP, MMP-17) is a glycosylphosphatidylinositol-anchored proteinase. J Biol Chem 274:34260-34266

Jin X, Yagi M, Akiyama N, Hirosaki T, Higashi S, Lin CY, Dickson RB, Kitamura H, Miyazaki K (2006) Matriptase activates stromelysin (MMP-3) and promotes tumor growth and angiogenesis. Cancer Sci 97:1327-1334

Joos L, He JQ, Shepherdson MB, Connett JE, Anthonisen NR, Pare PD, Sandford AJ (2002) The role of matrix metalloproteinase polymorphisms in the rate of decline in lung function. Hum Mol Genet 11:569-576

Jungel A, Ospelt C, Lesch M, Thiel M, Sunyer T, Schorr O, Michel BA, Gay RE, Kolling C, Flory C, Gay S, Neidhart M (2010) Effect of the oral application of a highly selective MMP-13 inhibitor in three different animal models of rheumatoid arthritis. Ann Rheum Dis 69:898-902

Kang T, Yi J, Guo A, Wang X, Overall CM, Jiang W, Elde R, Borregaard N, Pei D (2001) Subcellular distribution and cytokineand chemokine-regulated secretion of leukolysin/MT6-MMP/ MMP-25 in neutrophils. J Biol Chem 276:21960-21968

Khatwa UA, Kleibrink BE, Shapiro SD, Subramaniam M (2010) MMP-8 promotes polymorphonuclear cell migration through collagen barriers in obliterative bronchiolitis. J Leukoc Biol 87:69-77

Kjeldsen L, Johnsen AH, Sengelov H, Borregaard N (1993) Isolation and primary structure of NGAL, a novel protein associated with human neutrophil gelatinase. J Biol Chem 268:10425-10432

Klein G, Vellenga E, Fraaije MW, Kamps WA, de Bont ES (2004) The possible role of matrix metalloproteinase (MMP)-2 and MMP-9 in cancer, e.g. acute leukemia. Crit Rev Oncol Hematol 50:87-100
Knauper V, Osthues A, DeClerck YA, Langley KE, Blaser J, Tschesche H (1993) Fragmentation of human polymorphonuclear-leucocyte collagenase. Biochem J 291(Pt 3):847-854

Knauper V, Lopez-Otin C, Smith B, Knight G, Murphy G (1996) Biochemical characterization of human collagenase-3. J Biol Chem 271:1544-1550

Knauper V, Bailey L, Worley JR, Soloway P, Patterson ML, Murphy G (2002) Cellular activation of proMMP-13 by MT1-MMP depends on the C-terminal domain of MMP-13. FEBS Lett 532:127-130

Koch S, Volkmar CM, Kolb-Bachofen V, Korth HG, Kirsch M, Horn AH, Sticht H, Pallua N, Suschek CV (2009) A new redoxdependent mechanism of MMP-1 activity control comprising reduced low-molecular-weight thiols and oxidizing radicals. J Mol Med 87:261-272

Korpi JT, Kervinen V, Maklin H, Vaananen A, Lahtinen M, Laara E, Ristimaki A, Thomas G, Ylipalosaari M, Astrom P, Lopez-Otin C, Sorsa T, Kantola S, Pirila E, Salo T (2008) Collagenase-2 (matrix metalloproteinase-8) plays a protective role in tongue cancer. Br J Cancer 98:766-775

Krampert M, Bloch W, Sasaki T, Bugnon P, Rulicke T, Wolf E, Aumailley M, Parks WC, Werner S (2004) Activities of the matrix metalloproteinase stromelysin-2 (MMP-10) in matrix degradation and keratinocyte organization in wounded skin. Mol Biol Cell 15:5242-5254

Lafleur MA, Handsley MM, Knauper V, Murphy G, Edwards DR (2002) Endothelial tubulogenesis within fibrin gels specifically requires the activity of membrane-type-matrix metalloproteinases (MT-MMPs). J Cell Sci 115:3427-3438

Lang R, Braun M, Sounni NE, Noel A, Frankenne F, Foidart JM, Bode W, Maskos K (2004) Crystal structure of the catalytic domain of MMP-16/MT3-MMP: characterization of MT-MMP specific features. J Mol Biol 336:213-225

Leeman MF, Curran S, Murray GI (2002) The structure, regulation, and function of human matrix metalloproteinase-13. Crit Rev Biochem Mol Biol 37:149-166

Leeuwenburgh MA, Geurink PP, Klein T, Kauffman HF, van der Marel GA, Bischoff R, Overkleeft HS (2006) Solid-phase synthesis of succinylhydroxamate peptides: functionalized matrix metalloproteinase inhibitors. Org Lett 8:1705-1708

Lehrke M, Greif M, Broedl UC, Lebherz C, Laubender RP, Becker A, von Ziegler F, Tittus J, Reiser M, Becker C, Goke B, Steinbeck G, Leber AW, Parhofer KG (2009) MMP-1 serum levels predict coronary atherosclerosis in humans. Cardiovasc Diabetol 8:50

Lehti K, Valtanen H, Wickstrom SA, Lohi J, Keski-Oja J (2000) Regulation of membrane-type-1 matrix metalloproteinase activity by its cytoplasmic domain. J Biol Chem 275:15006-15013

Lemjabbar H, Gosset P, Lamblin C, Tillie I, Hartmann D, Wallaert B, Tonnel AB, Lafuma C (1999) Contribution of $92 \mathrm{kDa}$ gelatinase/ type IV collagenase in bronchial inflammation during status asthmaticus. Am J Respir Crit Care Med 159:1298-1307

Levi E, Fridman R, Miao HQ, Ma YS, Yayon A, Vlodavsky I (1996) Matrix metalloproteinase 2 releases active soluble ectodomain of fibroblast growth factor receptor 1. Proc Natl Acad Sci USA 93:7069-7074

Li Q, Park PW, Wilson CL, Parks WC (2002) Matrilysin shedding of syndecan-1 regulates chemokine mobilization and transepithelial efflux of neutrophils in acute lung injury. Cell 111:635-646

Lijnen HR, Arza B, Van Hoef B, Collen D, Declerck PJ (2000) Inactivation of plasminogen activator inhibitor-1 by specific proteolysis with stromelysin-1 (MMP-3). J Biol Chem 275:37645-37650

Liu Z, Zhou X, Shapiro SD, Shipley JM, Twining SS, Diaz LA, Senior RM, Werb Z (2000) The serpin alpha1-proteinase inhibitor is a critical substrate for gelatinase B/MMP-9 in vivo. Cell 102:647-655 
Llano E, Pendas AM, Freije JP, Nakano A, Knauper V, Murphy G, Lopez-Otin C (1999) Identification and characterization of human MT5-MMP, a new membrane-bound activator of progelatinase a overexpressed in brain tumors. Cancer Res 59:2570 2576

Lochter A, Galosy S, Muschler J, Freedman N, Werb Z, Bissell MJ (1997) Matrix metalloproteinase stromelysin-1 triggers a cascade of molecular alterations that leads to stable epithelial-tomesenchymal conversion and a premalignant phenotype in mammary epithelial cells. J Cell Biol 139:1861-1872

Lopez-Boado YS, Wilson CL, Parks WC (2001) Regulation of matrilysin expression in airway epithelial cells by Pseudomonas aeruginosa flagellin. J Biol Chem 276:41417-41423

Maatta M, Talvensaari-Mattila A, Turpeenniemi-Hujanen T, Santala M (2007) Matrix metalloproteinase-2 (MMP-2) and -9 (MMP-9) and their tissue inhibitors (TIMP-1 and TIMP-2) in differential diagnosis between low malignant potential (LMP) and malignant ovarian tumours. Anticancer Res 27:2753-2758

Madlener M, Werner S (1997) cDNA cloning and expression of the gene encoding murine stromelysin-2 (MMP-10). Gene 202:75-81

Maeda S, Sawai T, Uzuki M, Takahashi Y, Omoto H, Seki M, Sakurai M (1995) Determination of interstitial collagenase (MMP-1) in patients with rheumatoid arthritis. Ann Rheum Dis 54:970-975

Maeda H, Okamoto T, Akaike T (1998) Human matrix metalloprotease activation by insults of bacterial infection involving proteases and free radicals. Biol Chem 379:193-200

Maisi P, Prikk K, Sepper R, Pirila E, Salo T, Hietanen J, Sorsa T (2002) Soluble membrane-type 1 matrix metalloproteinase (MT1-MMP) and gelatinase A (MMP-2) in induced sputum and bronchoalveolar lavage fluid of human bronchial asthma and bronchiectasis. APMIS 110:771-782

Marchenko GN, Strongin AY (2001) MMP-28, a new human matrix metalloproteinase with an unusual cysteine-switch sequence is widely expressed in tumors. Gene 265:87-93

Marchenko GN, Ratnikov BI, Rozanov DV, Godzik A, Deryugina EI, Strongin AY (2001) Characterization of matrix metalloproteinase-26, a novel metalloproteinase widely expressed in cancer cells of epithelial origin. Biochem J 356:705-718

Mari BP, Anderson IC, Mari SE, Ning Y, Lutz Y, Kobzik L, Shipp MA (1998) Stromelysin-3 is induced in tumor/stroma cocultures and inactivated via a tumor-specific and basic fibroblast growth factor-dependent mechanism. J Biol Chem 273:618-626

Martinez A, Oh HR, Unsworth EJ, Bregonzio C, Saavedra JM, Stetler-Stevenson WG, Cuttitta F (2004) Matrix metalloproteinase-2 cleavage of adrenomedullin produces a vasoconstrictor out of a vasodilator. Biochem $\mathrm{J}$ 383:413-418

Matrisian LM, Glaichenhaus N, Gesnel MC, Breathnach R (1985) Epidermal growth factor and oncogenes induce transcription of the same cellular mRNA in rat fibroblasts. EMBO J 4:14351440

Matrisian LM, Bowden GT, Krieg P, Furstenberger G, Briand JP, Leroy P, Breathnach R (1986) The mRNA coding for the secreted protease transin is expressed more abundantly in malignant than in benign tumors. Proc Natl Acad Sci USA 83:9413-9417

Matsumoto S, Katoh M, Saito S, Watanabe T, Masuho Y (1997) Identification of soluble type of membrane-type matrix metalloproteinase- 3 formed by alternatively spliced mRNA. Biochim Biophys Acta 1354:159-170

Matsuno H, Yudoh K, Watanabe Y, Nakazawa F, Aono H, Kimura T (2001) Stromelysin-1 (MMP-3) in synovial fluid of patients with rheumatoid arthritis has potential to cleave membrane bound Fas ligand. J Rheumatol 28:22-28

Mattu TS, Royle L, Langridge J, Wormald MR, Van den Steen PE, Van Damme J, Opdenakker G, Harvey DJ, Dwek RA, Rudd PM (2000) O-glycan analysis of natural human neutrophil gelatinase
B using a combination of normal phase-HPLC and online tandem mass spectrometry: implications for the domain organization of the enzyme. Biochemistry 39:15695-15704

Matute-Bello G, Wurfel MM, Lee JS, Park DR, Frevert CW, Madtes DK, Shapiro SD, Martin TR (2007) Essential role of MMP-12 in Fas-induced lung fibrosis. Am J Respir Cell Mol Biol 37:210-221

Matute-Bello G, Wurfel MM, Lee JS, Frevert CW, Shapiro S, Martin TR (2008) MMP-12 mediates fibrosis after lung injury in mice. Proc Am Thorac Soc 5:361-362

Matziari M, Dive V, Yiotakis A (2007) Matrix metalloproteinase 11 (MMP-11; stromelysin-3) and synthetic inhibitors. Med Res Rev 27:528-552

Mautino G, Oliver N, Chanez P, Bousquet J, Capony F (1997) Increased release of matrix metalloproteinase- 9 in bronchoalveolar lavage fluid and by alveolar macrophages of asthmatics. Am J Respir Cell Mol Biol 17:583-591

McCawley LJ, Matrisian LM (2001) Matrix metalloproteinases: they're not just for matrix anymore!. Curr Opin Cell Biol 13:534-540

McDonnell S, Matrisian LM (1990) Stromelysin in tumor progression and metastasis. Cancer Metastasis Rev 9:305-319

McQuibban GA, Gong JH, Wong JP, Wallace JL, Clark-Lewis I, Overall CM (2002) Matrix metalloproteinase processing of monocyte chemoattractant proteins generates CC chemokine receptor antagonists with anti-inflammatory properties in vivo. Blood 100:1160-1167

Mercapide J, Lopez DC, Castresana JS, Klein-Szanto AJ (2003) Stromelysin-1/matrix metalloproteinase-3 (MMP-3) expression accounts for invasive properties of human astrocytoma cell lines. Int J Cancer 106:676-682

Mercer BA, Wallace AM, Brinckerhoff CE, D'Armiento JM (2009) Identification of a cigarette smoke-responsive region in the distal MMP-1 promoter. Am J Respir Cell Mol Biol 40:4-12

Miyamori H, Takino T, Kobayashi Y, Tokai H, Itoh Y, Seiki M, Sato $\mathrm{H}$ (2001) Claudin promotes activation of pro-matrix metalloproteinase- 2 mediated by membrane-type matrix metalloproteinases. J Biol Chem 276:28204-28211

Mochizuki S, Shimoda M, Shiomi T, Fujii Y, Okada Y (2004) ADAM28 is activated by MMP-7 (matrilysin-1) and cleaves insulin-like growth factor binding protein-3. Biochem Biophys Res Commun 315:79-84

Moilanen M, Sorsa T, Stenman M, Nyberg P, Lindy O, Vesterinen J, Paju A, Konttinen YT, Stenman UH, Salo T (2003) Tumorassociated trypsinogen-2 (trypsinogen-2) activates procollagenases (MMP-1, -8, -13) and stromelysin-1 (MMP-3) and degrades type I collagen. Biochemistry 42:5414-5420

Mok W, Boucher Y, Jain RK (2007) Matrix metalloproteinases-1 and -8 improve the distribution and efficacy of an oncolytic virus. Cancer Res 67:10664-10668

Molloy KJ, Thompson MM, Jones JL, Schwalbe EC, Bell PR, Naylor AR, Loftus IM (2004) Unstable carotid plaques exhibit raised matrix metalloproteinase-8 activity. Circulation 110:337-343

Morrison CJ, Butler GS, Bigg HF, Roberts CR, Soloway PD, Overall CM (2001) Cellular activation of MMP-2 (gelatinase A) by MT2-MMP occurs via a TIMP-2-independent pathway. J Biol Chem 276:47402-47410

Motrescu ER, Blaise S, Etique N, Messaddeq N, Chenard MP, Stoll I, Tomasetto C, Rio MC (2008) Matrix metalloproteinase-11/ stromelysin-3 exhibits collagenolytic function against collagen VI under normal and malignant conditions. Oncogene 27:63476355

Muller D, Quantin B, Gesnel MC, Millon-Collard R, Abecassis J, Breathnach R (1988) The collagenase gene family in humans consists of at least four members. Biochem J 253:187-192

Muller M, Trocme C, Lardy B, Morel F, Halimi S, Benhamou PY (2008) Matrix metalloproteinases and diabetic foot ulcers: the 
ratio of MMP-1 to TIMP-1 is a predictor of wound healing. Diabet Med 25:419-426

Murnane MJ, Cai J, Shuja S, McAneny D, Klepeis V, Willett JB (2009) Active MMP-2 effectively identifies the presence of colorectal cancer. Int J Cancer 125:2893-2902

Murphy G, Knauper V (1997) Relating matrix metalloproteinase structure to function: why the "hemopexin" domain? Matrix Biol 15:511-518

Murphy G, Cockett MI, Ward RV, Docherty AJ (1991) Matrix metalloproteinase degradation of elastin, type IV collagen and proteoglycan. A quantitative comparison of the activities of $95 \mathrm{kDa}$ and $72 \mathrm{kDa}$ gelatinases, stromelysins- 1 and -2 and punctuated metalloproteinase (PUMP). Biochem J 277(Pt 1):277-279

Murphy G, Nguyen Q, Cockett MI, Atkinson SJ, Allan JA, Knight CG, Willenbrock F, Docherty AJ (1994) Assessment of the role of the fibronectin-like domain of gelatinase A by analysis of a deletion mutant. J Biol Chem 269:6632-6636

Nagase H (1997) Activation mechanisms of matrix metalloproteinases. Biol Chem 378:151-160

Nagase H (1998) Cell surface activation of progelatinase A (proMMP-2) and cell migration. Cell Res 8:179-186

Nagase H, Woessner JF Jr (1999) Matrix metalloproteinases. J Biol Chem 274:21491-21494

Nakahama K, Yoshimura K, Marumoto R, Kikuchi M, Lee IS, Hase T, Matsubara H (1986) Cloning and sequencing of Serratia protease gene. Nucleic Acids Res 14:5843-5855

Nakamura M, Miyamoto S, Maeda H, Ishii G, Hasebe T, Chiba T, Asaka M, Ochiai A (2005) Matrix metalloproteinase-7 degrades all insulin-like growth factor binding proteins and facilitates insulin-like growth factor bioavailability. Biochem Biophys Res Commun 333:1011-1016

Nawrocki B, Polette M, Marchand V, Monteau M, Gillery P, Tournier JM, Birembaut P (1997) Expression of matrix metalloproteinases and their inhibitors in human bronchopulmonary carcinomas: quantificative and morphological analyses. Int J Cancer 72:556564

Nguyen M, Arkell J, Jackson CJ (2000) Activated protein C directly activates human endothelial gelatinase A. J Biol Chem 275:9095-9098

Nguyen M, Arkell J, Jackson CJ (2001) Human endothelial gelatinases and angiogenesis. Int J Biochem Cell Biol 33:960-970

Nie J, Pei D (2003) Direct activation of pro-matrix metalloproteinase2 by leukolysin/membrane-type 6 matrix metalloproteinase/ matrix metalloproteinase 25 at the asn(109)-Tyr bond. Cancer Res 63:6758-6762

Niiya D, Egawa N, Sakamoto T, Kikkawa Y, Shinkawa T, Isobe T, Koshikawa N, Seiki M (2009) Identification and characterization of Lutheran blood group glycoprotein as a new substrate of membrane-type 1 matrix metalloproteinase 1 (MT1-MMP): a systemic whole cell analysis of MT1-MMP-associating proteins in A431 cells. J Biol Chem 284:27360-27369

Noel A, Santavicca M, Stoll I, L'Hoir C, Staub A, Murphy G, Rio MC, Basset P (1995) Identification of structural determinants controlling human and mouse stromelysin-3 proteolytic activities. J Biol Chem 270:22866-22872

Noel A, Boulay A, Kebers F, Kannan R, Hajitou A, Calberg-Bacq CM, Basset P, Rio MC, Foidart JM (2000) Demonstration in vivo that stromelysin-3 functions through its proteolytic activity. Oncogene 19:1605-1612

Ogata Y, Enghild JJ, Nagase H (1992) Matrix metalloproteinase 3 (stromelysin) activates the precursor for the human matrix metalloproteinase 9. J Biol Chem 267:3581-3584

Ogiwara K, Takano N, Shinohara M, Murakami M, Takahashi T (2005) Gelatinase A and membrane-type matrix metalloproteinases 1 and 2 are responsible for follicle rupture during ovulation in the medaka. Proc Natl Acad Sci USA 102:8442-8447
Opdenakker G, Masure S, Grillet B, Van Damme J (1991) Cytokinemediated regulation of human leukocyte gelatinases and role in arthritis. Lymphokine Cytokine Res 10:317-324

Ota I, Li XY, Hu Y, Weiss SJ (2009) Induction of a MT1-MMP and MT2-MMP-dependent basement membrane transmigration program in cancer cells by Snail 1. Proc Natl Acad Sci USA 106: 20318-20323

Pardo A, Selman M (2005) MMP-1: the elder of the family. Int J Biochem Cell Biol 37:283-288

Park HI, Ni J, Gerkema FE, Liu D, Belozerov VE, Sang QX (2000) Identification and characterization of human endometase (matrix metalloproteinase-26) from endometrial tumor. J Biol Chem 275:20540-20544

Parks WC, Shapiro SD (2001) Matrix metalloproteinases in lung biology. Respir Res 2:10-19

Peake NJ, Khawaja K, Myers A, Jones D, Cawston TE, Rowan AD, Foster HE (2005) Levels of matrix metalloproteinase (MMP)-1 in paired sera and synovial fluids of juvenile idiopathic arthritis patients: relationship to inflammatory activity, MMP-3 and tissue inhibitor of metalloproteinases-1 in a longitudinal study. Rheumatology (Oxford) 44:1383-1389

Pei D (1999a) Identification and characterization of the fifth membrane-type matrix metalloproteinase MT5-MMP. J Biol Chem 274:8925-8932

Pei D (1999b) Leukolysin/MMP25/MT6-MMP: a novel matrix metalloproteinase specifically expressed in the leukocyte lineage. Cell Res 9:291-303

Pei D, Weiss SJ (1995) Furin-dependent intracellular activation of the human stromelysin-3 zymogen. Nature 375:244-247

Pei D, Majmudar G, Weiss SJ (1994) Hydrolytic inactivation of a breast carcinoma cell-derived serpin by human stromelysin-3. J Biol Chem 269:25849-25855

Pendas AM, Knauper V, Puente XS, Llano E, Mattei MG, Apte S, Murphy G, Lopez-Otin C (1997) Identification and characterization of a novel human matrix metalloproteinase with unique structural characteristics, chromosomal location, and tissue distribution. J Biol Chem 272:4281-4286

Pyke C, Ralfkiaer E, Huhtala P, Hurskainen T, Dano K, Tryggvason $\mathrm{K}$ (1992) Localization of messenger RNA for Mr 72,000 and 92,000 type IV collagenases in human skin cancers by in situ hybridization. Cancer Res 52:1336-1341

Quantin B, Murphy G, Breathnach R (1989) Pump-1 cDNA codes for a protein with characteristics similar to those of classical collagenase family members. Biochemistry 28:5327-5334

Ra HJ, Parks WC (2007) Control of matrix metalloproteinase catalytic activity. Matrix Biol 26:587-596

Radichev IA, Remacle AG, Sounni NE, Shiryaev SA, Rozanov DV, Zhu W, Golubkova NV, Postnova TI, Golubkov VS, Strongin AY (2009) Biochemical evidence of the interactions of membrane type1 matrix metalloproteinase (MT1-MMP) with adenine nucleotide translocator (ANT): potential implications linking proteolysis with energy metabolism in cancer cells. Biochem J 420:37-47

Rio MC (2005) From a unique cell to metastasis is a long way to go: clues to stromelysin-3 participation. Biochimie 87:299-306

Risau W (1997) Mechanisms of angiogenesis. Nature 386:671-674

Robinet A, Fahem A, Cauchard JH, Huet E, Vincent L, Lorimier S, Antonicelli F, Soria C, Crepin M, Hornebeck W, Bellon G (2005) Elastin-derived peptides enhance angiogenesis by promoting endothelial cell migration and tubulogenesis through upregulation of MT1-MMP. J Cell Sci 118:343-356

Saarialho-Kere UK, Pentland AP, Birkedal-Hansen H, Parks WC, Welgus HG (1994) Distinct populations of basal keratinocytes express stromelysin-1 and stromelysin-2 in chronic wounds. J Clin Invest 94:79-88

Salmela MT, Pender SL, Karjalainen-Lindsberg ML, Puolakkainen P, Macdonald TT, Saarialho-Kere U (2004) Collagenase-1 (MMP-1), 
matrilysin-1 (MMP-7), and stromelysin-2 (MMP-10) are expressed by migrating enterocytes during intestinal wound healing. Scand J Gastroenterol 39:1095-1104

Sato H, Takino T, Okada Y, Cao J, Shinagawa A, Yamamoto E, Seiki M (1994) A matrix metalloproteinase expressed on the surface of invasive tumour cells. Nature 370:61-65

Saus J, Quinones S, Otani Y, Nagase H, Harris ED Jr, Kurkinen M (1988) The complete primary structure of human matrix metalloproteinase-3. Identity with stromelysin. J Biol Chem 263:6742-6745

Schettler A, Thorn H, Jockusch BM, Tschesche H (1991) Release of proteinases from stimulated polymorphonuclear leukocytes. Evidence for subclasses of the main granule types and their association with cytoskeletal components. Eur J Biochem 197:197-202

Schonbeck U, Mach F, Libby P (1998) Generation of biologically active IL-1 beta by matrix metalloproteinases: a novel caspase-1independent pathway of IL-1 beta processing. J Immunol 161:3340-3346

Senior RM, Griffin GL, Mecham RP (1980) Chemotactic activity of elastin-derived peptides. J Clin Invest 66:859-862

Shapiro SD, Griffin GL, Gilbert DJ, Jenkins NA, Copeland NG, Welgus HG, Senior RM, Ley TJ (1992) Molecular cloning, chromosomal localization, and bacterial expression of a murine macrophage metalloelastase. J Biol Chem 267:4664-4671

Shapiro SD, Kobayashi DK, Ley TJ (1993) Cloning and characterization of a unique elastolytic metalloproteinase produced by human alveolar macrophages. J Biol Chem 268:2382423829

Shapiro S, Khodalev O, Bitterman H, Auslender R, Lahat N (2010) Different activation forms of MMP-2 oppositely affect the fate of endothelial cells. Am J Physiol Cell Physiol 298:C942-C951

Shipley JM, Wesselschmidt RL, Kobayashi DK, Ley TJ, Shapiro SD (1996) Metalloelastase is required for macrophage-mediated proteolysis and matrix invasion in mice. Proc Natl Acad Sci USA 93:3942-3946

Sier CFM, Casetta G, Verheijen JH, Tizzani A, Agape V, Kos J, Blasi F, Hanemaaijer R (2000) Enhanced urinary gelatinase activities (matrix metalloproteinases 2 and 9) are associated with earlystage bladder carcinoma: a comparison with clinically used tumor markers. Clin Cancer Res 6:2333-2340

Silence J, Lupu F, Collen D, Lijnen HR (2001) Persistence of atherosclerotic plaque but reduced aneurysm formation in mice with stromelysin-1 (MMP-3) gene inactivation. Arterioscler Thromb Vasc Biol 21:1440-1445

Sirum KL, Brinckerhoff CE (1989) Cloning of the genes for human stromelysin and stromelysin 2: differential expression in rheumatoid synovial fibroblasts. Biochemistry 28:8691-8698

Sohail A, Sun Q, Zhao H, Bernardo MM, Cho JA, Fridman R (2008) MT4-(MMP17) and MT6-MMP (MMP25), a unique set of membrane-anchored matrix metalloproteinases: properties and expression in cancer. Cancer Metastasis Rev 27:289-302

Somiari SB, Somiari RI, Heckman CM, Olsen CH, Jordan RM, Russell SJ, Shriver CD (2006) Circulating MMP2 and MMP9 in breast cancer-potential role in classification of patients into low risk, high risk, benign disease and breast cancer categories. Int J Cancer 119:1403-1411

Sopata I, Dancewicz AM (1974) Presence of a gelatin-specific proteinase and its latent form in human leucocytes. Biochim Biophys Acta 370:510-523

Sounni NE, Roghi C, Chabottaux V, Janssen M, Munaut C, Maquoi E, Galvez BG, Gilles C, Frankenne F, Murphy G, Foidart JM, Noel A (2004) Up-regulation of vascular endothelial growth factor-A by active membrane-type 1 matrix metalloproteinase through activation of Src-tyrosine kinases. J Biol Chem 279:13564-13574
Stadlmann S, Pollheimer J, Moser PL, Raggi A, Amberger A, Margreiter R, Offner FA, Mikuz G, Dirnhofer S, Moch H (2003) Cytokine-regulated expression of collagenase-2 (MMP-8) is involved in the progression of ovarian cancer. Eur $\mathrm{J}$ Cancer 39:2499-2505

Stenman M, Paju A, Hanemaaijer R, Tervahartiala T, Leminen A, Stenman UH, Konttinen YT, Sorsa T (2003) Collagenases (MMP-1, -8 and -13) and trypsinogen-2 in fluid from benign and malignant ovarian cysts. Tumour Biol 24:9-12

Sternlicht MD, Werb Z (2001) How matrix metalloproteinases regulate cell behavior. Annu Rev Cell Dev Biol 17:463-516

Stocker W, Bode W (1995) Structural features of a superfamily of zinc-endopeptidases: the metzincins. Curr Opin Struct Biol 5:383-390

Sun Q, Weber CR, Sohail A, Bernardo MM, Toth M, Zhao H, Turner JR, Fridman R (2007) MMP25 (MT6-MMP) is highly expressed in human colon cancer, promotes tumor growth, and exhibits unique biochemical properties. J Biol Chem 282:2199822010

Takemura M, Azuma C, Kimura T, Tokugawa Y, Miki M, Ono M, Saji F, Tanizawa O (1992) Malignant cell-specific gelatinase activity in human endometrial carcinoma. Cancer 70:147-151

Takino T, Sato H, Shinagawa A, Seiki M (1995) Identification of the second membrane-type matrix metalloproteinase (MT-MMP-2) gene from a human placenta cDNA library. MT-MMPs form a unique membrane-type subclass in the MMP family. J Biol Chem 270:23013-23020

Tang BL (2001) ADAMTS: a novel family of extracellular matrix proteases. Int J Biochem Cell Biol 33:33-44

Templeton NS, Stetler-Stevenson WG (1991) Identification of a basal promoter for the human Mr 72,000 type IV collagenase gene and enhanced expression in a highly metastatic cell line. Cancer Res 51:6190-6193

Toth M, Hernandez-Barrantes S, Osenkowski P, Bernardo MM, Gervasi DC, Shimura Y, Meroueh O, Kotra LP, Galvez BG, Arroyo AG, Mobashery S, Fridman R (2002) Complex pattern of membrane type 1 matrix metalloproteinase shedding. Regulation by autocatalytic cells surface inactivation of active enzyme. J Biol Chem 277:26340-26350

Ueno H, Nakamura H, Inoue M, Imai K, Noguchi M, Sato H, Seiki M, Okada Y (1997) Expression and tissue localization of membrane-types 1, 2, and 3 matrix metalloproteinases in human invasive breast carcinomas. Cancer Res 57:2055-2060

Uria JA, Lopez-Otin C (2000) Matrilysin-2, a new matrix metalloproteinase expressed in human tumors and showing the minimal domain organization required for secretion, latency, and activity. Cancer Res 60:4745-4751

Vaalamo M, Karjalainen-Lindsberg ML, Puolakkainen P, Kere J, Saarialho-Kere U (1998) Distinct expression profiles of stromelysin-2 (MMP-10), collagenase-3 (MMP-13), macrophage metalloelastase (MMP-12), and tissue inhibitor of metalloproteinases-3 (TIMP-3) in intestinal ulcerations. Am J Pathol 152:1005-1014

Vaisar T, Kassim SY, Gomez IG, Green PS, Hargarten S, Gough PJ, Parks WC, Wilson CL, Raines EW, Heinecke JW (2009) MMP-9 sheds the beta2 integrin subunit (CD18) from macrophages. Mol Cell Proteomics 8:1044-1060

Van den Steen PE, Dubois B, Nelissen I, Rudd PM, Dwek RA, Opdenakker G (2002) Biochemistry and molecular biology of gelatinase B or matrix metalloproteinase-9 (MMP-9). Crit Rev Biochem Mol Biol 37:375-536

Van Wart HE, Birkedal-Hansen H (1990) The cysteine switch: a principle of regulation of metalloproteinase activity with potential applicability to the entire matrix metalloproteinase gene family. Proc Natl Acad Sci USA 87:5578-5582 
Vincenti MP (2001) The matrix metalloproteinase (MMP) and tissue inhibitor of metalloproteinase (TIMP) genes. Transcriptional and posttranscriptional regulation, signal transduction and cell-typespecific expression. Methods Mol Biol 151:121-148

Vincenti MP, Brinckerhoff CE (2002) Transcriptional regulation of collagenase (MMP-1, MMP-13) genes in arthritis: integration of complex signaling pathways for the recruitment of gene-specific transcription factors. Arthritis Res 4:157-164

Vincenti MP, Clark IM, Brinckerhoff CE (1994) Using inhibitors of metalloproteinases to treat arthritis. Easier said than done? Arthritis Rheum 37:1115-1126

Vu TH, Shipley JM, Bergers G, Berger JE, Helms JA, Hanahan D, Shapiro SD, Senior RM, Werb Z (1998) MMP-9/gelatinase B is a key regulator of growth plate angiogenesis and apoptosis of hypertrophic chondrocytes. Cell 93:411-422

Wang X, Yi J, Lei J, Pei D (1999a) Expression, purification and characterization of recombinant mouse MT5-MMP protein products. FEBS Lett 462:261-266

Wang Y, Johnson AR, Ye QZ, Dyer RD (1999b) Catalytic activities and substrate specificity of the human membrane type 4 matrix metalloproteinase catalytic domain. J Biol Chem 274:33043-33049

Wang FQ, So J, Reierstad S, Fishman DA (2005) Matrilysin (MMP-7) promotes invasion of ovarian cancer cells by activation of progelatinase. Int J Cancer 114:19-31

Wang F, Reierstad S, Fishman DA (2006) Matrilysin over-expression in MCF-7 cells enhances cellular invasiveness and pro-gelatinase activation. Cancer Lett 236:292-301

Weiss SJ, Peppin G, Ortiz X, Ragsdale C, Test ST (1985) Oxidative autoactivation of latent collagenase by human neutrophils. Science 227:747-749

White JM (2003) ADAMs: modulators of cell-cell and cell-matrix interactions. Curr Opin Cell Biol 15:598-606

Wiesen JF, Werb Z (1996) The role of stromelysin-1 in stromalepithelial interactions and cancer. Enzyme Protein 49:174-181

Wilson CL, Matrisian LM (1996) Matrilysin: an epithelial matrix metalloproteinase with potentially novel functions. Int $\mathrm{J}$ Biochem Cell Biol 28:123-136

Wilson CL, Ouellette AJ, Satchell DP, Ayabe T, Lopez-Boado YS, Stratman JL, Hultgren SJ, Matrisian LM, Parks WC (1999)
Regulation of intestinal alpha-defensin activation by the metalloproteinase matrilysin in innate host defense. Science 286:113-117

Witty JP, Wright JH, Matrisian LM (1995) Matrix metalloproteinases are expressed during ductal and alveolar mammary morphogenesis, and misregulation of stromelysin-1 in transgenic mice induces unscheduled alveolar development. Mol Biol Cell 6:1287-1303

Woessner JF Jr (1991) Matrix metalloproteinases and their inhibitors in connective tissue remodeling. FASEB J 5:2145-2154

Woessner JF Jr, Taplin CJ (1988) Purification and properties of a small latent matrix metalloproteinase of the rat uterus. J Biol Chem 263:16918-16925

Yana I, Weiss SJ (2000) Regulation of membrane type-1 matrix metalloproteinase activation by proprotein convertases. Mol Biol Cell 11:2387-2401

Yoshiyama Y, Asahina M, Hattori T (2000) Selective distribution of matrix metalloproteinase-3 (MMP-3) in Alzheimer's disease brain. Acta Neuropathol 99:91-95

Yu WH, Woessner JF Jr, McNeish JD, Stamenkovic I (2002) CD44 anchors the assembly of matrilysin/MMP-7 with heparin-binding epidermal growth factor precursor and ErbB4 and regulates female reproductive organ remodeling. Genes Dev 16:307-323

Zhang J, Sarkar S, Yong VW (2005) The chemokine stromal cell derived factor-1 (CXCL12) promotes glioma invasiveness through MT2matrix metalloproteinase. Carcinogenesis 26:2069-2077

Zhao H, Bernardo MM, Osenkowski P, Sohail A, Pei D, Nagase H, Kashiwagi M, Soloway PD, DeClerck YA, Fridman R (2004) Differential inhibition of membrane type 3 (MT3)-matrix metalloproteinase (MMP) and MT1-MMP by tissue inhibitor of metalloproteinase (TIMP)-2 and TIMP-3 rgulates pro-MMP-2 activation. J Biol Chem 279:8592-8601

Zhou Z, Apte SS, Soininen R, Cao R, Baaklini GY, Rauser RW, Wang J, Cao Y, Tryggvason K (2000) Impaired endochondral ossification and angiogenesis in mice deficient in membrane-type matrix metalloproteinase I. Proc Natl Acad Sci USA 97:4052-4057

Zigrino P, Kuhn I, Bauerle T, Zamek J, Fox JW, Neumann S, Licht A, Schorpp-Kistner M, Angel P, Mauch C (2009) Stromal expression of MMP-13 is required for melanoma invasion and metastasis. J Invest Dermatol 129:2686-2693 